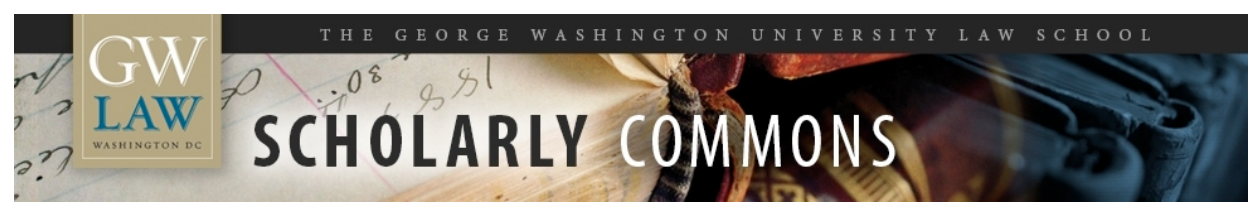

\title{
The Other Half Of The Abortion Right
}

Thomas Colby

George Washington University Law School, tcolby@law.gwu.edu

Follow this and additional works at: https://scholarship.law.gwu.edu/faculty_publications

Part of the Law Commons

\section{Recommended Citation}

Colby, Thomas, The Other Half Of The Abortion Right (2018). The Other Half of the Abortion Right, 20 University of Pennsylvania Journal of Constitutional Law 1043 (2018).; GWU Law School Public Law Research Paper No. 2018-46; GWU Legal Studies Research Paper No. 2018-46. Available at SSRN: https://ssrn.com/abstract=3269572

This Article is brought to you for free and open access by the Faculty Scholarship at Scholarly Commons. It has been accepted for inclusion in GW Law Faculty Publications \& Other Works by an authorized administrator of Scholarly Commons. For more information, please contact spagel@law.gwu.edu. 


\title{
THE OTHER HALF OF THE ABORTION RIGHT
}

\author{
Thomas B. Colby* \\ TABLE OF CONTENTS
}

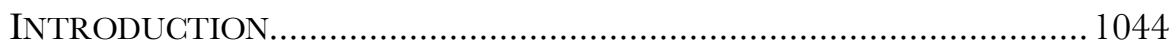

I. WHY THE PURPOSE PRONG MATters ............................................ 1050

II. UNDUE BURDEN, PURPOSE, AND THE TIERS OF SCRUTINY ........... 1055

III. What Does the PuRPose Prong ProhibIt? .............................. 1063

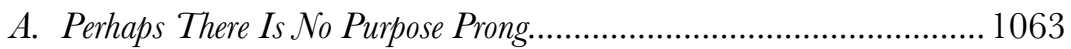

B. But Really There Is ..................................................................... 1067

1. Permissible Purposes............................................................ 1071

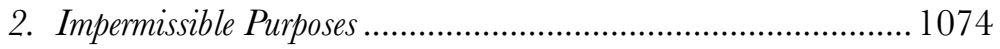

3. Putting it All Together ............................................................. 1076

IV. How Prevalent Must the ImPermissible PuRPose

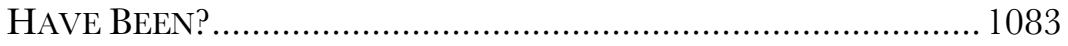

V. How Does One Prove an ImPermissible Purpose?................ 1090

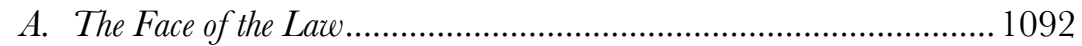

B. A Comparison with the Regulation of Similar Practices....................... 1092

C. A Bad "Fit" Between Means and Ends............................................... 1094

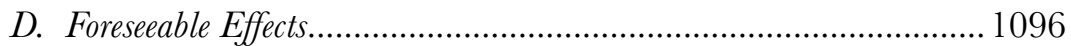

E. Legislative History and Statements of the Legislators and Others Involved in the Legislative Process................................................... 1097

F. The Historical Background and the Specific Sequence of Events

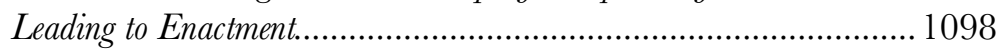

G. Departures from Normal Lawmaking Procedures.............................. 1099

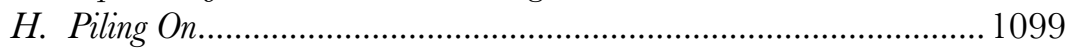

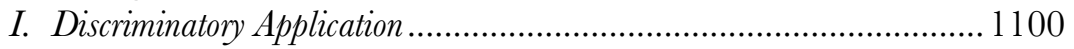

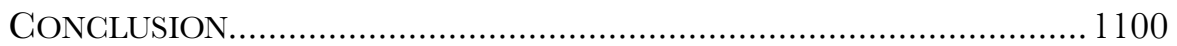

* John Theodore Fey Research Professor of Law, the George Washington University Law School. 


\section{INTRODUCTION}

It has now been more than a quarter century since the Supreme Court revolutionized the law of abortion rights in Planned Parenthood v. Casey ${ }^{1}$ by unexpectedly ${ }^{2}$ concluding that "the essential holding of Roe $v$. Wade should be retained and... reaffirmed,"3 yet simultaneously rejecting much of Roe's doctrinal framework and replacing its demand for strict scrutiny with a novel and more lenient "undue burden" test. ${ }^{4}$ Under that test, a state regulation that has the incidental effect of increasing the cost or decreasing the availability of pre-viability abortions is unconstitutional if it imposes an "undue burden" on the woman's right to choose to end her pregnancy. "A finding of an undue burden," explained Justices O'Connor, Kennedy, and Souter in their landmark plurality opinion, "is a shorthand for the conclusion that a state regulation has the purpose or effect of placing a substantial obstacle in the path of a woman seeking an abortion of a nonviable fetus." 6

By ratcheting down the level of scrutiny, and granting the states more leeway to regulate, Casey ushered in a new era of legislative restrictions on abortion rights. ${ }^{7}$ As inevitable court challenges to those restrictions followed, a vast body of case law interpreting and defining the undue burden test has emerged.

505 U.S. 833 (1992)

2 See Linda J. Wharton \& Kathryn Kolbert, Preserving Roe v. Wade... When You Win Only Half the Loaf, 24 Stan. L. \& POL'Y REv. 143, 144 (2013) (noting that "most court watchers at the time ... fully believed that the Court was prepared to overrule Roe").

Casey, 505 U.S. at 846.

See id. at 872-79 (O’Connor, Kennedy, \& Souter,JJ., plurality opinion).

See id. at 874 .

Id. at 877.

In the twenty-plus years since Casey was decided, all the Justices who have expressed an opinion have agreed that the joint opinion in Casey, including the portions joined only by its three authors (the "plurality opinion") as well as those joined by Justices Blackmun and Stevens (the "majority opinion"), constitutes the Court's authoritative ruling under the rule in Marks v. United States.... .

Stephen G. Gilles, Why the Right to Elective Abortion Fails Casey's Own Interest-Balancing Methodologyand Why It Matters, 91 Notre Dame L. Rev. 691, 696 n.26 (2015) (citing Marks v. United States, 430 U.S. 188, 193 (1977)); see also Marks, 430 U.S. at 193 (holding that when "no single rationale explaining the result enjoys the assent of five Justices, the holding of the Court may be viewed as that position taken by those Members who concurred in the judgments on the narrowest grounds" (citation and internal quotation marks omitted) (quoting Gregg v. Georgia, 428 U.S. 153, 169 n.15 (1976) (Stewart, Powell, \& Stevens, JJ., plurality opinion))).

7 See, e.g., Clarke D. Forsythe, Facilitating Roe's Unraveling: The Strategic Significance of Defending Life on Its 10th Anniversary, in AMS. United fOR Life, Defending Life 2015: Celebrating Ten Years of Defending Life xi, xi (Denise Burke ed., 2015) (“[Casey] has given more deference to the states, allowing them to enact stronger limits on abortion and permitting those limits to be enforced by state officials. As the Supreme Court has retreated from its belief that the mere access to abortion must be protected at all costs to a belief that states should be permitted to act in furtherance of their interests in protecting both maternal health and unborn life, many states have moved forward to fill the vacuum, enacting limitations and regulations on abortion designed to protect both women and their unborn children."). 
But there is something peculiar about that body of precedent. Casey phrased the undue burden test in the disjunctive: "purpose or effect." An abortion regulation will be constitutional only if it neither (1) has the purpose of imposing an undue burden, nor (2) has the effect of doing so. One would expect to find numerous cases evaluating, and often striking down, legislation under each of those prongs. In particular, one would expect to see the first prong - the purpose prong - doing quite a lot of work in the case law. A very large number of post-Casey legislative limits on abortion rights - especially those enacted in recent years - would seem, at least arguably, to run afoul of that prong.

Hundreds of state laws seeking to curtail access to abortion have been enacted in the past ten years alone. ${ }^{8}$ The proponents and authors of those laws have freely admitted that their purpose, in substantial part, is to "fence in abortion" further and further, while paving the way for the eventual overruling of Roe. ${ }^{9}$ Recognizing that Roe will not be overruled until the composition of the Supreme Court is changed, the leading legal strategists in the pro-life community have advocated in the interim an incremental approach that seeks to slowly chip away at abortion rights, eventually paring them down to the bone. ${ }^{10}$ Americans United for Life, the self-described "legal arm of the prolife movement," 11 each year publishes Defending Life, a guide for legislative action that serves as "the pro-life playbook" insofar as its suggestions and model statutes have provided the roadmap for the recent avalanche of abortion-

8 See Neal Devins, Rethinking fudicial Minimalism: Abortion Politics, Party Polarization, and the Consequences of Returning the Constitution to Elected Government, 69 VAND. L. REV. 935, 975 (2016) (noting that 205 abortion restrictions were enacted from 2011 to 2013); Letter from Charmaine Yoest, President \& Chief Exec. Officer, Ams. United for Life, to Friends, in Defending Life 2015: Celebrating TEN YEARS OF DEFENDING LifE, supra note 7, at ix, x (boasting that there were 332 "pro-life" laws enacted between 2006 and 2015).

9 Clark D. Forsythe, The Road Map to Reversing Roe v. Wade, in AMS. UNITED FOR Life, DEFENDING Life 2009: Proven Strategies for a Pro-Life America 63, 64 (Denise M. Burke ed., 2009) ("Until the [Supreme Court] can be changed sufficiently, more must be done to fence in abortion ...."); id. ("Interim and incremental reductions of Roe (and the abortion license) are necessary to pave the way to a complete overruling."); id. (advocating "passing state regulations that will produce new test cases that can scale back Roe").

10 See Dawn Johnsen, "TRAP"ing Roe in Indiana and a Common-Ground Alternative, 118 YALE L.J. 1356, 1359-60 (2009). For instance, two of the leading figures in the pro-life movement have opined on "how best to advance the pro-life cause at present," concluding that, because "we must do what we can until the day when we can do more," the ideal strategy is to pursue "incremental' efforts [such] as clinic regulations (which often shut down clinics), parental involvement, waiting periods, and informed consent." Memorandum from James Bopp, Jr. \& Richard E. Coleson 1, 6 (Aug. 7, 2007); see also Clarke D. Forsythe, A Legal Strategy to Overtum Roe v. Wade After Webster: Some Lessons from Lincoln, 1991 BYU L. REV. 519, 548 ("The goal, as long as Roe v. Wade remains good law, is the passage and successful defense of abortion legislation that will work to chip away at and eventually cause the Supreme Court to overrule Roe v. Wade.").

11 DavidJ. Shafer, Forward to AMS. United FOR LiFe, DEFENDING Life 2010: Proven STRATEGiEs FOR A PRO-LIFE AMERICA 13, 14 (Denise M. Burke ed., 2010) (internal quotation marks omitted). 
restricting legislation nationwide. ${ }^{12}$ In its own words, Defending Life outlines a "legislative strategy that ... restricts abortion as much as possible in light of federal court obstruction"13 - a strategy, that is, with the express purpose of restricting abortion rights and reducing women's access to abortion.

Central to this strategy is a slew of laws that are often referred to by abortion rights advocates as "TRAP" laws - targeted regulation of abortion providers. ${ }^{14}$ These laws subject abortion providers to more extensive and burdensome regulations than comparable medical practitioners. ${ }^{15}$ They ostensibly seek to protect women's health, but in fact are often not justified by legitimate health concerns. ${ }^{16}$ While these laws are always carefully couched in the language of women's health, Defending Life admits that they are also intended, in substantial part, "to curtail . . Roe"17 and to "reduce the abortion rate."18

Consider, for instance, the Texas law recently reviewed by the Supreme Court in Whole Woman's Health $v$. Hellerstedt. ${ }^{19}$ That law required physicians who perform abortions to have admitting privileges at a nearby hospital, and mandated that the health and safety standards for abortion clinics must be equivalent to those for ambulatory surgical centers. ${ }^{20}$ On its face, the law appeared to be intended only to protect women - an assertion echoed in the official legislative history. ${ }^{21}$ Yet, the day after the bill passed in the Texas Senate, Texas Lieutenant Governor David Dewhurst posted on Twitter a

12 Yoest, supra note 8, at ix (internal quotation marks omitted). Texas Governor Rick Perry explains that the "many ideas and suggestions contained in the pages of" Defending Life "play[] a key role in developing and promoting legislation in all 50 states." Letter from Rick Perry, Governor, Tex., in Defending Life 2014: The Women's Protection Project 4, 5 (Denise M. Burke ed., 2014).

13 Clark D. Forsythe, The Road Map to Overturning Roe v. Wade: What Can the States Do Now?, in DeFENDing Life 2010: Proven STRATEgies FOR A Pro-Life AMERICA, supra note 11, at 33, 35.

14 See Linda Greenhouse \& Reva B. Siegel, Casey and the Clinic Closings: When "Protecting Health" Obstructs Choice, 125 YALE L.J. 1428, 1432 (2016) (reading Casey to prohibit some TRAP laws).

15 Amalia W. Jorns, Note, Challenging Warrantless Inspections of Abortion Providers: A New Constitutional Strategy, 105 COLUM. L. REV. 1563, 1563 (2005).

16 See Johnsen, supra note 10, at 1369 (defining a TRAP law as a law that "targeted abortion providers with onerous regulations that were not supported by health or safety needs").

17 Forsythe, supra note 9, at 65 (articulating the need to "work to promote the understanding among state legislators and policy groups that regulations which emphasize the risks to women and the need to protect women (such as informed consent, abortion clinic regulations, etc.) will be more effective means to curtail or overturn Roe than abortion prohibitions").

18 Denise M. Burke, Planned Parenthood: What Can Be Done to Stop Their Radical Agenda for America?, in DefENding Life 2009: Proven Strategies For a Pro-Life America, supra note 9, at 99, 103 (calling for "[e]nactment of more common-sense, medically-appropriate regulations of abortion, including informed consent, ultrasound requirements, parental involvement, and abortion clinic regulations" as "[t]hese types of regulations have been proven to reduce the abortion rate").

19136 S. Ct. 2292 (2016).

20 Id. at 2300

21 See Brief for Respondents at 31, Whole Woman's Health v. Hellerstedt, 136 S. Ct. 2292 (2016) (No. 15-274), 2016 WL 344496 (asserting that the bill was drafted in order to "increase the health and safety' of abortion patients and provide them with 'the highest standard of health care" (quoting Senate Research Ctr., Bill Analysis, Tex. H.B. 2, 83d Leg., 2d Spec. Sess., at 2 (July 11, 2013)). 
graphic produced by an abortion rights group lamenting that the bill would force most clinics in the state to close, and that the law would therefore "essentially ban abortion statewide." 22 Dewhurst added, "We fought to pass [the bill] thru the Senate last night, \& this is why!"'23

Because so many of these TRAP laws and other regulations were enacted with a goal of restricting abortion rights as much as possible, one would expect the purpose prong to be doing a lot of work in the case law. But it is not. In fact, it is barely doing any work at all. The vast majority of the cases applying Casey's undue burden test ignore the purpose prong altogether, and analyze the law solely through the lens of effect. ${ }^{24}$ For instance, in Hellerstedt, the Supreme Court began its opinion by announcing that, under Casey, the law would not stand if it had either the "purpose or effect" of placing a substantial obstacle in the path of a woman seeking an abortion - suggesting through the added emphasis that both prongs would prove relevant to the inquiry. ${ }^{25}$ But the Court then went on to analyze only whether the law had the effect of imposing an undue burden, ultimately striking the law down on that ground alone, notwithstanding the considerable evidence of a purpose to restrict abortion rights. ${ }^{26}$

Thus, as Casey celebrates its twenty-fifth birthday, its articulated twopronged test has seemingly morphed into a single-pronged balancing test: "The rule announced in Casey ... requires that courts consider the burdens a law imposes on abortion access together with the benefits those laws confer," so as to determine whether the law, in effect, "constitutes an undue burden" on the right to choose an abortion. ${ }^{27}$ Half of the abortion right has fallen away.

It is not surprising that the purpose prong has withered. For one thing, it got off to a tenuous start. The Casey plurality announced the purpose prong, but: (1) it did not clearly explain what is and is not a permissible

22 David Dewhurst (@DavidHDewhurst), TwITTER (June 19, 2003, 7:41 AM), https://twitter.com/ davidhdewhurst/status/347363442497302528.

$23 \quad I d$.

24 See Priscilla J. Smith, If the Purpose Fits: The Two Functions of Casey's Purpose Inquiry, 71 WASH. \& LEE L. REV. 1135, 1136 (2014) ("Most litigation over the constitutionality of abortion regulation has argued through the lens of 'effect'... [and] overlooks the other prong of the undue burden test ...."); Linda J. Wharton et al., Preserving the Core of Roe: Reflections on Planned Parenthood v. Casey, 18 YALEJ.L. \& FeMINISM 317, 377-78 (2006) ("Lower courts have tended to omit discussion of the purpose prong or to conflate it with the effects prong."); Lucy E. Hill, Note, Seeking Liberty's Refuge: Analyzing Legislative Purpose Under Casey's Undue Burden Standard, 81 FORDHAM L. Rev. 365, 369 (2012) (noting that "few cases have dealt with the purpose prong" and that "the vast majority of cases have focused on whether an abortion law has an unconstitutional effect"); Jenny K. Jarrard, Note, The Failed Purpose Prong: Women's Right to Choose in Theory, Not in Fact, Under the Undue Burden Standard, 18 LEWIS \& CLARK L. REV. 469, 471 (2014) (noting that "one half of the barrier, the socalled purpose prong, has been effectively ignored ... by the courts for the past 20 years"). Hellerstedt, 136 S. Ct. at 2300.

26 See id. (concluding that each requirement "places a substantial obstacle in the path of women seeking a previability abortion," and thus "constitutes an undue burden on abortion access").

27 Id. at 2309 
purpose; (2) it made no effort to analyze how one might go about proving an impermissible purpose; ${ }^{28}$ and (3) it did not even bother to seriously apply the purpose prong to the Pennsylvania statute at issue in the case - instead deciding the case solely on effects grounds, even while upholding most of the law. ${ }^{29}$ In subsequent cases, the Supreme Court has rarely paid much attention to the purpose prong, ${ }^{30}$ except once to question whether an independent purpose prong really exists at all - openly (albeit in dicta) expressing doubt about the very "premise ... that a legislative purpose to interfere with the constitutionally protected right to abortion without the effect of interfering with that right . . . could render [a] law invalid." 31

With no firm foundation on which to build, and no guidance from the Supreme Court (save the dicta questioning the prong's very existence), the lower courts have been left at sea. The case law in the few lower courts that have attempted to apply the purpose prong is, in the words of one commentator, "a mess, creating rampant confusion and decisions at odds on theoretical and practical levels." 32

28 See infra note 235 and accompanying text ("The Casey Court provided little, if any, instruction regarding the type of inquiry lower courts should undertake to determine whether a regulation has the 'purpose' of imposing an undue burden on a woman's right to seek an abortion." (quoting Okpalobi v. Foster, 190 F.3d 337, 354 (5th Cir. 1999))).

29 See Karlin v. Foust, 188 F.3d 446, 493 (7th Cir. 1999) (noting that "the Court in Casey devoted little attention toward analyzing the purpose behind Pennsylvania's abortion statute"); Hill, supra note 24, at 385 ("Although Casey outlines a disjunctive test analyzing the 'purpose or effect' of placing a substantial obstacle in the path of a woman seeking an abortion, the Casey Court only seriously analyzes the effect of such laws ....."); Julie F. Kowitz, Note, Not Your Garden Variety Tort Reform: Statutes Barring Claims for Wrongful Life and Wrongful Birth Are Unconstitutional Under the Purpose Prong of Planned Parenthood v. Casey, 61 BROOK. L. REv. 235, 251 (1995) ("Although it extensively analyzed the various effects of the challenged legislation, the Casey plurality devoted virtually no attention to analyzing the purpose behind [it].”).

30 See Jorns, supra note 15, at 1586 (noting that "the purpose prong of the Casey undue burden standard has received scant attention from the Supreme Court"). But see Gonzales v. Carhart, 550 U.S. 124, 156-60 (2007) (evaluating the purpose of a federal abortion regulation).

31 Mazurek v. Armstrong, 520 U.S. 968, 972 (1997); see also Foust, 188 F.3d at 494 ("Mazurek even went so far as to hint that it is questionable whether a statute enacted with the purpose of interfering with the woman's constitutionally protected right to abortion can be found unconstitutional if it does not have the actual effect of interfering with that right."); Caitlin E. Borgmann, Winter Count: Taking Stock of Abortion Rights After Casey and Carhart, 31 ForDHAM URB. L.J. 675, 691-92 n.107 (2004) ("Mazurek calls into question whether an improper purpose alone could ever suffice to invalidate an abortion restriction."); Wharton et al., supra note 24, at 344 (noting that, in this passage, "the Court flirted with the suggestion that an unconstitutional purpose standing alone would not suffice to invalidate an abortion restriction"); $c f$. Richard H. Fallon, Jr., Foreword: Implementing the Constitution, 111 HARV. L. REV. 54, 94 n.228 (1997) ("An alternative reading of Casey would treat the 'undue burden' standard as establishing an 'effects' test and as precluding the further protection that would be given by a 'purpose' test.").

32 Smith, supra note 24, at 1137; see also Hill, supra note 24, at 369 (noting that "few cases have dealt with the purpose prong, and what jurisprudence exists is far from clear"). 
The courts have received little help from the academy to clarify the confusion. Commentators, few of whom have made any serious effort to explore the purpose prong, do not have much of an idea what it means either. Indeed, they cannot agree on even the most simple and fundamental of questions: whether seeking to discourage women from choosing abortions is or is not a permissible governmental purpose. ${ }^{33}$

About the only thing that most commentators can agree on - and the reason why they cannot agree on anything else - is that the purpose prong appears to be incoherent and inherently contradictory. ${ }^{34}$ Casey simultaneously precludes the states from enacting a law whose "purpose ... is to place a substantial obstacle in the path of a woman seeking an abortion," 35 and permits the states to enact "regulation[s] aimed at the protection of fetal life." 36 How can that be? If a state enacts a law designed to reduce the availability or prevalence of abortion (as is often the intent behind abortion regulation), is that law unconstitutional for seeking to place a substantial obstacle in the path of a woman seeking to exercise her right, or is it constitutional for pursuing the permissible governmental purpose of protecting fetal life? ${ }^{37}$ Casey seems, nonsensically, to suggest both. ${ }^{38}$

33 Compare, e.g., Sarah E. Weber, An Attempt to Legislate Morality: Forced Ultrasounds as the Newest Tactic in Anti-Abortion Legislation, 45 TULSA L. REV. 359, 372 (2009) ("[T]he only purpose remaining is to discourage women from obtaining an abortion, which the Casey Court held would be an undue burden.”), and Ernest A. Young, Sorrell v. IMS Health and the End of the Constitutional Double Standard, 36 VT. L. REV. 903, 926-27 (2012) ("The Court has thus abandoned strict scrutiny of abortion regulations in favor of the undue burden standard, which is designed to distinguish between regulation that furthers the underlying right and regulation that, while perhaps disguised as helpful, is actually meant to discourage that right."), with, e.g. Jack M. Balkin, What Brown Teaches Us About Constitutional Theory, 90 VA. L. REV. 1537, 1568 (2004) (asserting that, under Casey, "states may even discourage abortions as long as they do not place an undue burden on the right"), and Thomas Ross, Despair and Redemption in the Feminist Nomos, 69 IND. L.J. 101, 133 (1993) ("The strict scrutiny standard is replaced by an 'undue burden' standard that sanctions substantial and intrusive regulation that is explicitly intended to dissuade, discourage, and make more difficult a woman's choice to have an abortion.").

34 See, e.g., ERWIN CHEMERINSKy, CONSTITUTIONAL LAW: PrinCiPLES AND POLICIES 849-50 (4th ed. 2011); Paula Abrams, Abortion Stigma: The Legacy of Casey, 35 WOMEN's RTS. L. REP. 299, 319 (2014).

35 Planned Parenthood of Se. Pa. v. Casey, 505 U.S. 833, 878 (1992) (plurality opinion).

$36 \quad I d$. at 873.

37 See Leah M. Litman, Response, Potential Life in the Doctrine, 95 Tex. L. REV. SEe ALSO 204, 205-06 (2017) (" $[\mathrm{O}]$ ne problem with the undue burden standard may be how the standard applies where the government purports to be expressing an interest in potential life. In those cases, how is a court to assess whether a law furthers that purpose, which Casey says is permissible, instead of the impermissible purpose of burdening a woman seeking an abortion?").

Erwin Chemerinsky explains the contradiction:

The problem is that the joint opinion says both that the state cannot act with the purpose of creating obstacles to abortion and that it can act with the purpose of discouraging abortion and encouraging childbirth. Every law adopted to limit abortion is for the purpose of discouraging abortions and encouraging childbirth. How is it to be decided which of these laws is invalid as an undue burden and which is permissible? The joint opinion simply says that the regulation "must not be an undue burden on the right." But this, of course, is circular; it offers no guidance as to which laws are an undue burden and which are not. 
This inherent contradiction explains why the purpose prong has atrophied. ${ }^{39}$ Courts cannot build coherent doctrine around an incoherent premise, and they eventually give up trying. The prong's disappearance may therefore not be surprising, but, as Part I of this Article explains, it is also not acceptable. Courts are forcing women to fight for their rights with one hand tied behind their backs - without the benefit of half of the constitutional test crafted to protect those rights. If we are going to untie that hand and restore the other half of the abortion right, however, we are first going to have to resolve its apparent conceptual incoherence. This Article attempts to do just that - to provide a much needed theoretical and doctrinal framework for applying the maligned and too-often-ignored purpose prong of the undue burden test. It seeks to answer a series of fundamental questions about the purpose prong that are raised, but not resolved, by Casey - questions that have fostered the confusion and apathy in the courts and commentary. First, what is the relationship between the purpose prong (and the undue burden test more generally) and the traditional tiers of scrutiny that typically govern substantive due process cases? Second, what does, and does not, count as an impermissible purpose? Is a law that seeks to protect potential life by reducing the prevalence of abortions motivated by a permissible purpose, or not? Third, what is the extent to which an impermissible purpose must have motivated the legislative action before the law can be deemed unconstitutional? Must it have been the sole purpose behind the law? The predominant purpose? A motivating purpose? Fourth, and finally, how can a challenger prove improper purpose? What evidence can (or must, or cannot) be brought to bear on the issue? Parts II through V seek to answer those questions, in that order.

\section{Why THE PURPOSE PRONG MATTERS}

Casey prohibits any "state regulation that has the purpose or effect of placing a substantial obstacle in the path of a woman seeking an abortion of a nonviable fetus." 40 Any regulation that actually has the effect of imposing an undue burden on the abortion right should be declared unconstitutional

CHEMERINSKY, supra note 34, at 850. One commentator writes of the difference between seeking to prevent abortions and seeking to protect potential life, "It is not clear to me that we have yet invented a razor fine enough to split this hair." Helena Silverstein, In the Matter of Anonymous, a Minor: Fetal Representation in Hearings to Waive Parental Consent for Abortion, 11 CORNELL J.L. \& PUB. POL'Y 69, 103 (2001).

39 See Jarrard, supra note 24, at 471-72 (arguing that " $[\mathrm{t}]$ he purpose prong fails as a workable standard" because of this "inherent tension" that "remains unresolved," and because the permissible purpose to protect fetal life would seem to justify every regulation of abortion such that "there is [never an] impermissible legislative purpose").

$40 \quad$ Casey, 505 U.S. at 877 (plurality opinion). 
under the effects prong, and the challengers will have no need for the purpose prong. The purpose prong comes into play, we might think, only for those laws that were intended to impose a substantial obstacle in the path of women seeking abortions, but did not actually do so.

The only circumstance in which a purpose inquiry would be useful would be when a state law was intended to create a substantial obstacle to women seeking abortions, but somehow failed to further this objective. That law would not technically produce an unduly burdensome effect, but could be invalidated on the grounds of its purpose alone. ${ }^{41}$

We might be tempted to wonder whether this category is close to a null set, and to further wonder why we should care about the tiny number of laws that might fall within it. If a regulation does not actually pose an obstacle to abortion rights, then why should we strike it down based on a nefarious purpose alone? ${ }^{42}$ No harm, no foul, right? ${ }^{33}$

41 Alan Brownstein, How Rights Are Infringed: The Role of Undue Burden Analysis in Constitutional Doctrine, 45 HASTINGS L.J. 867, 884 n.53 (1994).

42 See Calvin Massey, The Role of Governmental Purpose in Constitutional Fudicial Review, 59 S.C. L. REv. 1, 4-5 (2007) ("[T] he ... undue burden test ... ought to focus exclusively on whether such abortion regulations actually erect a substantial obstacle to ... an abortion. An ineffective government purpose to do so poses, by definition, an insubstantial obstacle to vindication of the constitutional autonomy right in question.").

43 Cf. McCreary Cty. v. ACLU, 545 U.S. 844, 901 (2005) (Scalia, J., dissenting) (" [] $\mathrm{t}$ is an odd jurisprudence that bases the unconstitutionality of a government practice that does not actually advance religion on the hopes of the government that it would do so."). But of course, our Establishment Clause jurisprudence does just that. See id. at 860 (majority opinion) ("When the government acts with the ostensible and predominant purpose of advancing religion, it violates that central Establishment Clause value of official religious neutrality, there being no neutrality when the government's ostensible object is to take sides."). 
Wrong. There are both consequentialist and non-consequentialist (deontological) reasons for policing governmental purposes ${ }^{44}$ in constitutional law. ${ }^{45}$ And those reasons are amply present here.

First the non-consequentialist justification: Purpose matters in its own right. As the Supreme Court once put it, a law that was enacted for an impermissible purpose, even when it does not have an impermissible effect, "has no legitimacy at all under our Constitution."46 Government actions "animated by such a purpose have no credentials whatsoever; for '[a]cts generally lawful may become unlawful when done to accomplish an unlawful end."'47

44 A brief word on terminology: Scholars sometimes seek to distinguish in this context among the terms "purpose," "motive," and "intent." See, e.g., Alexander M. Bickel, The Least DANGERous Branch: THE Supreme COURT AT THE BAR OF POlitics 209 (1962) (using "motive" to refer to the legislators' subjective reasons for acting, and "purpose" to refer to the intentions that can be objectively determined from the foreseeable effects of the act); Richard H. Fallon, Jr., Constitutionally Forbidden Legislative Intent, 130 HARV. L. REV. 523, 536 (2016) ("In this Article, I shall use the terms 'intent' and 'intentions' to denominate legislative aims and the terms 'motive' and 'motivations' to refer to the values or dispositions that lead people to adopt particular aims."). But courts, including the Supreme Court, do not draw such distinctions. See id. at 534-35 ("[T] he Court almost invariably treats the terms 'intentions' and 'purposes' as synonymous. In addition, it most frequently uses 'motivations' in the same conceptual hopper." (footnotes omitted)). Most commentators use the terms interchangeably, and do not believe that there is anything useful to be gained from trying to disentangle them. See, e.g., John Hart Ely, Legislative and Administrative Motivation in Constitutional Law, 79 YALE L.J. 1205, 1221 (1970) (noting that "it probably is, as a recent commentary has suggested, 'fruitless to attempt a principled articulation of the distinction between motive and purpose"' (footnotes omitted)); Robert C. Farrell, Legislative Purpose and Equal Protection's Rationality Review, 37 VILL. L. REV. 1, 5 (1992) (“Although attempts have been made to stake out different territories for these terms, these attempts have been generally unsuccessful and, in any case, have been ignored by the courts."); Elena Kagan, Private Speech, Public Purpose: The Role of Governmental Motive in First Amendment Doctrine, 63 U. CHI. L. REV. 413, 426 n.40 (1996) (noting that the Supreme Court uses "purpose," "motive," and "intent" interchangeably, and that "attempts by scholars to distinguish among these terms have proved unhelpful" (citations omitted)); Donald H. Regan, The Supreme Court and State Protectionism: Making Sense of the Dormant Commerce Clause, 84 MicH. L. REv. 1091, 1143 (1986) ("There is no useful distinction to be made between motive and purpose in the present context." (footnotes omitted)). Following that standard practice, this Article does not seek to distinguish among "purpose," "motive," and "intent." It uses all three terms to refer to the ends sought to be achieved by a law and the reasons why the legislature enacted it.

45 See, e.g., Kagan, supra note 44, at 425-26, 507 (noting that "courts may focus on motives because doing so will promote good outcomes... [and] because motives, in and of themselves, are what matter"); Alice Ristroph, State Intentions and the Law of Punishment, 98 J. CRIM. L \& CRIMINOLOGY 1353, 1385-86 (2008) (noting that "the relevance of state intentions can be defended with a consequentialist argument that focuses on the correlation between intentions and results; the claim is that by basing legal liability on certain intentions, we can prevent or reduce the bad results associated with those intentions," and that "[a]nother theory of government motive analysis focuses on certain kinds of intentions as being themselves intrinsically harmful"); Gordon G. Young, fustifying Motive Analysis in Fudicial Review, 17 WM. \& MARY BILL RTS. J. 191, 219-20 (2008) (noting that there are "two ... common moral philosophical views, consequentialism and deontology," that address "how ... motive analysis [may] seem to make moral sense and not just be a thoughtless extension").

46 City of Richmond v. United States, 422 U.S. 358, 378 (1975).

47 Id. at 378-79 (alteration in original) (quoting W. Union Tel. Co. v. Foster, 247 U.S. 105, 114 (1918)). 
As Ashutosh Bhagwat has explained, exclusive reliance on effects in constitutional law, without policing government motives, is "troubling" as "a theoretical matter" because it "ignores the fact that the Constitution ... constrains not merely how the government acts, but also, and more significantly, what the government may seek to do." 48 There is, in Charles Fried's words, "a moral dimension" to purpose review. 49 "The limits the Constitution places on government may be understood not just in terms of minimizing certain sorts of harms, but in ruling certain goals out of bounds for government altogether." 50 "These particular objectives are proscribed because their [very] pursuit is detrimental to society at large," 51 regardless of whether they are achieved.

To get at the point from a slightly different angle, some acts have "meaning regardless of their actual consequences ... expressing disregard or even contempt." 52 A law enacted for the purpose of undermining abortion rights expresses governmental contempt for constitutional rights, and for women's liberty. ${ }^{53}$ Such a law is inherently wrongful. The government's seeking to undermine this constitutional liberty is detrimental to society at large, regardless of whether it is successful in its pursuit.

As for the consequentialist reasons, it is well-settled that constitutional purpose review can prevent undesirable and unconstitutional outcomes. ${ }^{54}$ Because "[a]ctions taken for illegitimate reasons (motives) involving . . . fundamental rights are likely to correlate with especially bad consequences," ${ }_{55}$ and because it is not always possible or feasible for the courts to ascertain the actual effects of every law in every case, purpose review can be an efficient means of preventing unconstitutional harms. ${ }^{56}$

48 Ashutosh Bhagwat, Purpose Scrutiny in Constitutional Analysis, 85 CALIF. L. REV. 297, 309 (1997).

49 Charles Fried, Types, 14 Const. Comment. 55, 64 (1997).

$50 \quad I d$.

51 Paul Brest, Palmer v. Thompson: An Approach to the Problem of Unconstitutional Legislative Motive, 1971 SuP. CT. REv. 95, 116 n.109 (emphasis added).

52 JOSEPH RAZ, THE MORALITY OF FrEEDOM 378 (1986); see also Kagan, supra note 44, at 426 (noting the "nonconsequential, deontological considerations, relating to the stance or attitude we expect the government to adopt in relation to its citizens").

53 One can view this expressive harm in either consequentialist terms, see, e.g., Brest, supra note 51, at 116 n.109 (noting the "stigmatic injury distinct from the operative consequences of the law"); Fallon, supra note 44, at 530, or in deontological terms, see, e.g., Elizabeth S. Anderson \& Richard H. Pildes, Expressive Theories of Law: A General Restatement, 148 U. PA. L. REv. 1503, 1542-43 (2000) (noting "the distinctive character of expressive harms as harms inherent in the principle on which the laws are enacted, rather than in the causal consequences of the laws").

54 See Kagan, supra note 44, at 426 ("One reason for [constitutional] law to worry about government motive is itself consequential in nature; it refers to the predictable tendency of improperly motivated actions to have certain untoward effects."); Young, supra note 45, at 198 ("The everyday notion that people who aim at bad states of affairs are likely to bring them into existence goes a long way to justify concerns with motives.").

55 Young, supra note 45, at 227-28.

56 See Kagan, supra note 44, at 508-09 (noting that " $[\mathrm{t}]$ he problem with an effects-based standard is one of judicial administration" and that a "focus on governmental motive that marks First Amendment 
That is true in the abortion context. It is easy to imagine cases where the law's effect on women's rights, while significant, is hard to prove, but the purpose to hinder abortion rights is clearly demonstrable. For instance, in a state with a wide array of overlapping abortion restrictions - which is increasingly becoming the norm in many states - it can be difficult to disentangle the burdens imposed by the different restrictions, and to establish that any single restriction, on its own, presents a substantial obstacle to the exercise of the abortion right. ${ }^{57}$ The purpose prong is essential for policing those laws.

In addition, perhaps the most important consequentialist reason why the purpose prong matters is that it often provides the only opportunity to obtain a pre-enforcement injunction of an abortion regulation. Proving that a law has the effect of imposing an undue burden often requires analysis of the actual operation of the law in practice. ${ }^{58}$ Some courts have held that "it is an abuse of discretion for a district judge to issue a pre-enforcement injunction" based on a conclusion that a law will have the effect of creating an undue burden "while the effects of the law ... are open to debate." 59 Those courts insist that, when an abortion restriction is challenged under the effects prong, the state "is entitled to put its law into effect and have that law judged by its own consequences." 60 As such, the purpose prong is often the only way to

doctrine may function as a kind of proxy for an inquiry into the effects of a restriction of speech on an audience"); Young, supra note 45, at 224 (acknowledging that "[a] judge driven by consequentialism ... could not attempt a direct assessment of consequences in each case" ); cf. Katie R. Eyer, Ideological Drift and the Forgotten History of Intent, 51 HARV. G.R.-C.L. L. REV. 1, 12-22 (2016) (explaining how southern school districts used judicial reluctance to inquire into legislative intent as a means of perpetuating the massive resistance to Brown v. Board of Education, 347 U.S. 483 (1954)).

57 Caitlin Borgmann explains that

the manner in which the Justices administered the undue burden test in Casey highlights an additional, critical problem: the test's indifference to the cumulative burdens that multiple restrictions impose. The joint opinion addressed the challenged provisions seriatim, applying the undue burden standard to each. It examined how onerous each restriction was as if no other restrictions existed, ignoring how a woman would fare under the mounting obstacles as the Court upheld restriction upon restriction. Thus, under Casey, a single provision may not place a substantial obstacle in a woman's path to abortion. A state can, and many do, accomplish the same result, however, by erecting separate hurdles that cumulatively amount to what is surely a "substantial" obstacle for many women.

Borgmann, supra note 31, at 688 (footnotes omitted); see also Marlow Svatek, Seeing the Forest for the Trees: Why Courts Should Consider Cumulative Effects in the Undue Burden Analysis, 41 N.Y.U. REV. L. \& SOC. CHANGE 121, 125 (2017) (noting that many "courts narrowly consider only the direct causal effects of the challenged restriction to determine whether that restriction, in isolation, imposes an undue burden on a woman's right to obtain an abortion"); Valerie J. Pacer, Note, Salvaging the Undue Burden Standard - Is It a Lost Cause? The Undue Burden Standard and Fundamental Rights Analysis, 73 WASH. U. L.Q. 295, 310 n.93 (1995) ("The undue burden standard presents the danger that courts may not fully consider such cumulative effects, because the standard allows courts to consider obstacles to abortion one at a time.").

58 See, e.g., Johnsen, supra note 10, at 1384 (noting that "the precise effect of these regulations is difficult - perhaps impossible - to establish prior to their implementation and the passage of time").

59 A Woman's Choice-E. Side Women's Clinic v. Newman, 305 F.3d 684, 693 (7th Cir. 2002). 
strike down unconstitutional and invasive abortion restrictions before they go into operation and begin to irreparably deprive women of their rights. ${ }^{61}$

\section{UNDUE BURDEN, PURPOSE, AND THE TIERS OF SCRUTINY}

Casey reiterates (and more carefully develops) Roe's notion that the right to an abortion is a substantive right protected against state interference by the Fourteenth Amendment's Due Process Clause. ${ }^{62}$ Normally, we think of substantive due process cases as presenting a four-part doctrinal inquiry: "Is there a fundamental right; is the right infringed; is the infringement justified by a sufficient purpose; are the means sufficiently related to the ends sought?"63 Generally speaking, if the right is a fundamental one, its infringement triggers strict scrutiny - the state must prove that the law is narrowly tailored to a compelling state interest - and if the right is not fundamental, then its infringement triggers only rational basis review - the law survives unless it is not even rationally related to any legitimate state interest. ${ }^{64}$ Under Roe, abortion was a fundamental right protected by strict scrutiny. ${ }^{65}$ But Casey changed that.

Where does Casey's undue burden test fit into the doctrinal framework? The phrase "undue burden" first crept into abortion jurisprudence in the separate concurring and dissenting opinions of Justice O'Connor, who was using the phrase to address the second part of the four-part inquiry: the question antecedent to the level of scrutiny - the "threshold inquiry" - whether the right is infringed at all.66 But the Casey plurality makes clear that it is using the phrase very differently. ${ }^{67}$ Under Casey, undue burden is not a

61 See Wharton et al., supra note 24, at 377 ("Given the heavy burden of proving in a facial challenge that abortion restrictions will have an actual impermissible effect on women's access to abortion, the purpose prong of Casey's undue burden test becomes especially useful, because evidence of improper purpose is likely to be available pre-implementation, whereas proof of impermissible effect might not be."); Jarrard, supra note 24, at 508-10 (arguing that the purpose prong is "necessary as a preventative"); Kowitz, supra note 29, at 260-61 ("[L]itigants can challenge legislation under the purpose prong immediately.... [T] he facts necessary to satisfy Casey's substantiality requirement may be virtually impossible to prove before the challenged legislation goes into effect. Purposebased challenges, however, do not require a litigant to prove or predict harm.”).

62 See Planned Parenthood of Se. Pa. v. Casey, 505 U.S. 833, 846-53 (1992).

63 CHEMERINSKY, supra note 34 , at 849.

64 See Bhagwat, supra note 48, at 303, 305.

65 See Roe v. Wade, 410 U.S. 113, 155 (1973).

66 See City of Akron v. Akron Ctr. for Reprod. Health, Inc., 462 U.S. 416, 463 (1983) (O'Connor, J., dissenting) ("The 'undue burden' required in the abortion cases represents the required threshold inquiry that must be conducted before this Court can require a State to justify its legislative actions under the exacting 'compelling state interest' standard."); Wharton et al., supra note 24, at 332. And Justice O'Connor had set a very high standard for an "undue burden," requiring an "absolute obstacle[] or severe limitation[] on the abortion decision." Akron, 462 U.S. at 464.

67 See Casey, 505 U.S. at 877 (plurality opinion) ("To the extent that the opinions of the Court or of individual Justices use the undue burden standard in a manner that is inconsistent with this analysis, we set out what in our view should be the controlling standard."); Wharton et al., supra note 24, at 332. 
threshold inquiry triggering heightened scrutiny; rather, it is the entire inquiry. "[A]n undue burden is an unconstitutional burden." 68 Period.

Commentators often refer to Casey's undue burden test as "a middle position, a type of intermediate scrutiny." 69 This can be misleading. The undue burden inquiry is an intermediate one in the sense that it is more rigorous than rational basis, yet less rigorous than strict scrutiny. But it is certainly not "intermediate scrutiny" as that term is used elsewhere in constitutional law (such as in the law of sex discrimination) to mandate that a regulation must be substantially related to an important governmental interest. ${ }^{70}$ "Intermediate scrutiny" is one of the tiers of scrutiny; undue burden is not. Undue burden is a fundamentally different kind of test - one that is deployed in lieu of, rather than pursuant to, the traditional levels of scrutiny. ${ }^{71}$ Eschewing the tiered scrutiny framework, undue burden substitutes an entirely different mode of analysis for all three of the questions typically asked in cases involving fundamental rights: Is the right infringed; is the infringement justified by a sufficient purpose; and are the means sufficiently related to the ends sought?72 The undue burden test can therefore, in Erwin Chemerinsky's words, be "confusing to apply because it melds together three distinct issues." 73

That confusion is amplified by the fact that the Casey plurality opinion in some places unwisely employs language - like "legitimate interest" and "rational relationship" - that nebulously sounds in rational basis review. ${ }^{74}$ In dissent, Justice Scalia criticized the joint opinion's "description of the undue burden standard in terms more commonly associated with the rational-basis test," and lamented the "confusing equation of the two standards." 75 That confusion

68 Casey, 505 U.S. at 877 (plurality opinion).

69 Smith, supra note 24, at 1143; see also, e.g., Roy G. Spece,Jr., The Purpose Prong of Casey's Undue Burden Test and Its Impact on the Constitutionality of Abortion Insurance Restrictions in the Affordable Care Act or Its Progeny, 33 WhitTIER L. REv. 77, 79 (2011) ("This quasi-fundamental right is protected by the intermediate scrutiny of the undue burden test rather than by strict scrutiny.").

70 See Bhagwat, supra note 48, at 303.

71 See Sheldon Gelman, "Life" and "Liberty": Their Original Meaning, Historical Antecedents, and Current Significance in the Debate over Abortion Rights, 78 MiNN. L. REv. 585, 608-09 (1994) (noting that "[t]he undue burden test ... has no apparent connection to the framework of strict scrutiny and rational basis review" and seemingly "completely supplants the strict scrutiny framework"); Darrel C. Menthe, Reconciling Speech and Structural Elements in Sign Regulation, 44 GONZ. L. REv. 283, 288 (20082009) ("Fortunately, there is a means of escape from the tyranny of choosing a level of judicial scrutiny. The Supreme Court, in some areas of fundamental rights, has begun to move from applying a level of scrutiny to an 'undue burden' analysis.”).

72 See CHEMERinsky, supra note 34 , at 849.

73 Id.

74 See Emma Freeman, Note, Giving Casey Its Bite Back: The Role of Rational Basis Review in Undue Burden Analysis, 48 HARV. G.R.-C.L. L. REV. 279, 292 (2013) ("When defining the undue burden standard, the plurality repeatedly used terms like 'legitimate interest' and 'reasonable' or 'rational relationship' that traditionally appear in rational basis cases."); $i d$. at 293 ("References to rational basis also pepper Casey's implementation of the undue burden test.").

75 Planned Parenthood of Se. Pa. v. Casey, 510 U.S. 833, 986 n.4 (1992) (Scalia, J., concurring in the 
was made worse by the Court's subsequent decision in Gonzales v. Carhart, which declared, in purporting to employ the undue burden test, that the state had "a rational basis to act . . . in furtherance of its legitimate interests." 76

And the confusion is heightened even further when we try to figure out where in all of this the purpose prong fits in. ${ }^{77}$ Casey added the purpose prong to Justice O'Connor's earlier undue burden analysis, and at the same time eliminated the strict scrutiny inquiry that used to follow from a finding of undue burden. ${ }^{78}$ What was the addition of the purpose prong designed to accomplish?

Perhaps it was intended to substitute for one half of the now abolished strict scrutiny test. Tiered scrutiny inquiries consist of two parts: ends and means. How powerful is the state's interest (ends), and how widely does the law sweep in the course of serving that interest (means)? One might be tempted to suggest that Casey's effects prong was designed to substitute for the means part of the inquiry, and Casey's purpose prong was designed to substitute for the ends part.

But again, undue burden is not simply a new level of scrutiny, with its own analogous means and ends prongs. It is something different. And the relationship between purpose and the tiers of scrutiny is, in any event, more complicated. Courts sometimes speak of purpose as antecedent to the scrutiny question, rather than as part of the inquiry, and they sometimes speak of purpose as subsequent to the scrutiny inquiry. That is to say, a finding of discriminatory purpose can trigger strict scrutiny; in some contexts a law will be subject to strict scrutiny only if the court first concludes that it was motivated

judgment in part and dissenting in part).

76550 U.S. 124, 158 (2007). I suspect that the Court's stray use of rational basis language in Casey and Gonzales is an artifact of the fact that, prior to Casey,Justice O'Connor understood undue burden as a threshold inquiry necessary to trigger strict scrutiny. See supra note 66 and accompanying text. A statute that did not impose an undue burden was thus subject only to rational basis review. See City of Akron v. Akron Ctr. for Reprod. Health, Inc., 462 U.S. 416, 467 (1983) (O'Connor, J., dissenting). Even though the Court has completely reworked the nature of the undue burden test, judges have never quite let go of the notion that a law that does not impose an undue burden is still subject to rational basis review. See Gonzales, 550 U.S. at 158 ("Where it has a rational basis to act, and it does not impose an undue burden, the State may [regulate abortion] ...."); Planned Parenthood of Greater Tex. Surgical Health Servs. v. Abbott, 951 F. Supp. 2d 891, $898-99$ (W.D. Tex. 2013) (declaring that Casey calls for a two-part analysis: subjecting the law first to rational basis review, and then, if it survives, to the undue burden standard), rev'd in part, 748 F.3d 583 (5th Cir. 2014). This conceptualization adds to the confusion and should probably be abandoned. Cf. Brownstein, supra note 41, at 881 (explaining that "the 'undue burden' standard also subsumes the application of a rational basis standard of review to regulations that do not impose undue burdens"). But it does illustrate that undue burden is now an inquiry distinct from (though, on this formulation, imposed in addition to) the tiers of scrutiny.

77 See Smith, supra note 24, at 1136 ("[T] he Court was far from clear about the role the purpose inquiry in Casey was designed to serve, perhaps due to the evolving nature of liberty jurisprudence generally and instability in the tiers of review in particular.").

78 See Wharton et al., supra note 24, at 332. 
by an improper purpose. ${ }^{79}$ And a finding of discriminatory purpose can be the goal of a strict scrutiny inquiry; in John Hart Ely's words, strict scrutiny is often used as "a way of 'flushing out' unconstitutional motivation." 80

So purpose can be used to trigger the heightened scrutiny inquiry, can be a portion of the scrutiny inquiry (the ends question), and can be the goal of the heightened scrutiny inquiry. Confusing indeed. And here - as we try to figure out what role purpose is supposed to play in a brand new test that is designed to replace the traditional heightened scrutiny framework altogetherthe confusion is multiplied even further still by the fact that, even though purpose is generally a question of ends, Casey speaks of it in means terms:

A finding of an undue burden is a shorthand for the conclusion that a state regulation has the purpose or effect of placing a substantial obstacle in the path of a woman seeking an abortion of a nonviable fetus. A statute with this purpose is invalid because the means chosen by the State to further the interest in potential life must be calculated to inform the woman's free choice, not hinder it. ${ }^{81}$

In this regard, the purpose prong seems to suffer from built-in conceptual muddle.

For instance, one commentator writes of "Casey's adoption of an intermediate scrutiny analysis requiring scrutiny of the state interest claimed and a fit analysis in the name of "purpose." ${ }_{22}$ This is an understandable statement, in light of the passage just quoted. We might even consider it a valiant attempt to make sense of the seemingly incomprehensible. But still, in calling both for intermediate scrutiny analysis under the undue burden test, and for a fit analysis in the name of purpose, it is an invitation to make doctrinal hash.

If we are going to refer to the undue burden test as a level of scrutiny (which we should not do), and therefore conclude that it calls for a fit analysis (which we should not assume), then it makes no sense to suggest that the fit analysis is primarily a question of purpose. In a scrutiny inquiry, fit is a question of tailoring - of means, rather than ends. ${ }^{83}$ Of course, as just noted,

79 See City of Mobile v. Bolden, 446 U.S. 55, 113 (1980) (Marshall, J., dissenting) ("Under Washington v. Davis, 426 U.S. 229 (1976), a showing of discriminatory purpose is necessary to impose strict scrutiny on facially neutral classifications having a racially discriminatory impact.”).

80 JOHN HART Ely, DEMOCRAGY AND DisTRUST: A THEORY OF JUdicial REVIEW 146 (1980); see also Johnson v. California, 543 U.S. 499, 505-06 (2005) (declaring that one of the primary "reasons for strict scrutiny" is that it can "ssmoke out' illegitimate" laws that were "motivated by an invidious purpose" (quoting City of Richmond v. J.A. Croson Co., 488 U.S. 469, 493 (1989) (plurality opinion))); Adam Winkler, Fatal in Theory and Strict in Fact: An Empirical Analysis of Strict Scrutiny in the Federal Courts, 59 VAND. L. REV. 793, 802-03 (2006).

81 Planned Parenthood of Se. Pa. v. Casey, 505 U.S. 833, 877 (1992) (plurality opinion) (emphasis added).

82 Smith, supra note 24, at 1148.

83 See James F. Blumstein, Racial Gerrymandering and Vote Dilution: Shaw v. Reno in Doctrinal Context, 26 RUTGERS L.J. 517, 590 (1995) ("This tight means/ends fit requirement is often referred to as narrow tailoring."); R. Randall Kelso, Considerations of Legislative Fit Under Equal Protection, Substantive Due Process, 
courts sometimes conduct a fit analysis in a scrutiny inquiry "in the name of purpose" in the sense that the fit analysis is designed to ferret out an impermissible legislative purpose. But when the Casey plurality tied "purpose" to "means" in the passage just quoted, it was not invoking the "smoking out" function of the fit analysis. The Court was not saying that where the means do not fit the proffered ends, we have reason to disbelieve the proffer and suspect nefarious ends instead. Rather, in asserting that the choice of means must not be calculated to hinder - that is, must not have the purpose of hindering - free choice, the Court was accepting the state's purpose at face value, rather than seeking to belie it. In other words, the Court was not saying that a choice of clumsy means would lead us to suspect that the real purpose was to hinder free choice. To the contrary, the Court was letting us know that, under its newly promulgated test, an avowed or otherwise determinable purpose to impose a substantial obstacle is impermissible: A "statute with this purpose is invalid because the means chosen by the State to further the interest in potential life must be calculated to inform the woman's free choice, not hinder it." ${ }^{4}$ This passage is discussing which motives are permissible and which are not - an ends inquiry. It has nothing to do with fit.

Casey's purpose prong thus does not invoke the traditional fit inquiry of the tiers of scrutiny, and it is not simply intended to serve the "smoking out" function that is sometimes a goal of heightened scrutiny. ${ }^{85}$

Nor, obviously, does it serve the "trigger" function of purpose that is sometimes antecedent to heightened scrutiny.

$[\mathrm{T}]$ he purpose prong within the undue burden test does not serve as the trigger of a standard of review in which the government might justify an improper purpose by, for example, showing a compelling or important government interest. Rather, the purpose prong is itself the standard of review, which flatly proscribes government actions that have an improper purpose. 86 Nor, for that matter, does the purpose prong simply substitute for the ends prong of a traditional scrutiny inquiry. In a scrutiny inquiry, the ends prong evaluates the strength of the state's interest ${ }^{87}$ - is it compelling? important?-

and Free Speech Doctrine: Separating Questions of Advancement, Relationship and Burden, 28 U. RICH. L. REV. 1279, 1303-04 (1994) (noting the various "kinds of 'fit' analysis [that] emerge under the burden inquiry of legislative fit analysis: ... 'precise tailoring,' 'least restrictive alternative,' or 'necessary;' . . . 'narrowly tailored,' 'narrowly drawn,' 'close fit,' or 'does not burden substantially more speech than necessary;' . . . 'reasonable fit,' 'rough proportionality,' 'reasonable and necessary,' or 'not clearly excessive;' and ... 'minimally rational,' 'not arbitrary or capricious,' or 'not wholly irrelevant”').

84 Casey, 505 U.S. at 877 (plurality opinion).

85 To be sure, courts can sometimes conduct a fit inquiry under the purpose prong in order to smoke out hidden impermissible purposes. See infra notes 262-69 and accompanying text. But the role and function of the purpose prong is not confined to that inquiry.

86 Spece, supra note 69, at 101.

87 See Marc Jonathan Blitz, Third Party Records Protection on the Model of Heightened Scrutiny, 66 OKLA. L. REV. 747, 777 (2014) ("The ends requirement demands that the government objective be justified 
whereas the purpose prong of the undue burden test evaluates the propriety of the state's motive. Those are fundamentally different questions. ${ }^{88}$

The conceptual muddling of undue burden and the tiers of scrutiny, combined with Casey's incomprehensibly tying together the purpose prong with a means inquiry, has led to rampant confusion in the law and the literature. Courts and commentators have been unable to let go of the tiers of scrutiny, and seem determined to wedge the undue burden test, including its purpose prong, into one of the tiers. One commentator recently canvassed the (few) lower court decisions that address the purpose prong and concluded that the Fifth, Eighth, and Tenth Circuits "apply a more searching review of the stated legislative purpose [under Casey], and apply heightened scrutiny to the laws," whereas the Fourth and Seventh Circuits "have invalidated laws on the basis of improper [legislative] purpose only if they fail rational basis review." "99 It is unlikely that most of those courts would agree with that characterization, as the cases generally do not openly articulate the inquiry in these terms - though they do indeed use language that naturally invokes the tiers of scrutiny. ${ }^{90}$ But the fact that commentators perceive the cases in this way - or themselves view the law in this way ${ }^{91}$ - illustrates the rampant confusion of undue burden with the tiers of scrutiny. ${ }^{92}$

by an interest of a certain strength.”).

88 It is true that the ends prong of the scrutiny analysis sometimes effectively evaluates the propriety of the state's interest. See, e.g., Romer v. Evans, 517 U.S. 620, 634 (1996) (" $\Pi]$ f the constitutional conception of 'equal protection of the laws' means anything, it must at the very least mean that a bare ... desire to harm a politically unpopular group cannot constitute a legitimate governmental interest." (alterations in original) (internal quotation marks omitted) (quoting U.S. Dep't of Agric. v. Moreno, 413 U.S. 528, 534 (1973))). But, in those instances, the courts might really just be evaluating the strength of the interest, and concluding that certain malicious interests are so weak as to not even qualify as legitimate. See, e.g., United States v. Extreme Assocs., Inc., 352 F. Supp. 2d 578, 594 (W.D. Pa. 2005) (discussing "public morality, which is no longer a legitimate, let alone compelling, state interest"), rev'd, 431 F.3d 150 (3d Cir. 2005); Samuel A. Marcosson, The Lesson of the Same-Sex Marriage Trial: The Importance of Pushing Opponents of Lesbian and Gay Rights to Their "Second Line of Defense," 35 U. LOUISVILLE J. FAM. L. 721, 748 n.86 (1997) ("After Romer, however, there is every reason to believe (and argue) that anti-gay morality is not even a legitimate state interest, much less a 'compelling' one...."). And, in any event, propriety review is surely not the primary purpose of the ends prong. 89 Hill, supra note 24, at 391-92.

90 See, e.g., Karlin v. Foust, 188 F.3d 446, 493 (7th Cir. 1999) ("Casey would seem to indicate that the Court would not scrutinize too closely the stated purpose or purposes of a regulation given the state's legitimate interest from the outset of a woman's pregnancy in persuading women to choose childbirth over abortion as long as the regulation was reasonably designed to further that interest.").

91 See, e.g., Karen A. Jordan, The Emerging Use of a Balancing Approach in Casey's Undue Burden Analysis, 18 U. PA. J. CONST. L. 657, 717 (2015) (arguing that Casey's "inquiry into purpose" is "a relational inquiry focusing on the purpose of the law, namely, whether the law is reasonably related to a legitimate state interest").

92 See, e.g., David F. Forte, Life, Heartbeat, Birth: A Medical Basis for Reform, 74 OHIO ST. L.J. 121, 132 n.71 (2013) (declaring that "different circuits have adopted different standards for determining an improper legislative purpose under the undue burden standard, ranging from heightened scrutiny to rational basis review"); B. Jessie Hill, The Constitutional Right to Make Medical Treatment Decisions: A 
That confusion has permeated not only the scattered cases on the purpose prong, but also the far more numerous cases on the effects prong. ${ }^{93}$ In its recent Hellerstedt decision, the Supreme Court attempted to partially clear up that confusion by insisting that it "is wrong to equate the judicial review applicable to the regulation of [this] constitutionally protected personal liberty with the less strict review" demanded by the rational basis test. ${ }^{94}$ That observation should apply to the purpose prong as well.

Hellerstedt further clarified that the undue burden test does sometimes call for something of a fit analysis - but generally under the effects prong, rather than the purpose prong. ${ }^{95}$ And that fit analysis is fundamentally different in nature from the one performed under the tiers of scrutiny. According to Hellerstedt, "[ $\mathrm{t}]$ he rule announced in Casey ... requires that courts consider the burdens a law imposes on abortion access together with the benefits those laws confer"-requires, that is, good old-fashioned judicial "balancing" to determine whether, in conjunction with the law's benefits, "any burden imposed on abortion access is 'undue."”96 In certain cases, a fit analysis can inform that balance; if the law does not actually serve the proffered purpose, or does not serve it well, then the benefits are in fact illusory or minimal, in which case the burden will likely outweigh them. ${ }^{97}$

Tale of Two Doctrines, 86 TEX. L. REV. 277, 319-21 (2007) (suggesting that the Gonzales Court may have been applying rational basis review to the purpose prong); Smith, supra note 24, at 1137-38 (arguing that "there is disagreement between the Circuits over the appropriate level of scrutiny of claimed state interests and whether this scrutiny is part of the purpose analysis"); Spece, supra note 69, at 100-01 (asserting that "[s] ome precedent ... guts the purpose prong by finding it met, in effect, if there is any imaginable legitimate [legislative] purpose that might be advanced," which improperly conflates it with rational basis review).

93 See, e.g., Planned Parenthood of Greater Tex. Surgical Health Servs. v. Abbott, 748 F.3d 583, 594 (5th Cir. 2014) ("Nothing in the Supreme Court's abortion jurisprudence deviates from the essential attributes of the rational basis test, which affirms a vital principle of democratic self-government.... Under rational basis review, courts must presume that the law in question is valid and sustain it so long as the law is rationally related to a legitimate state interest.").

94 Whole Woman's Health v. Hellerstedt, 136 S. Ct. 2292, 2309 (2016).

95 Id. at 2309-10.

96 Id. Prior to Hellerstedt, some courts and commentators were not convinced that the undue burden test called for judicial balancing. See, e.g., Gillian E. Metzger, Note, Unburdening the Undue Burden Standard: Orienting Casey in Constitutional furisprudence, 94 CoLuM. L. REv. 2025, 2033-34 (1994) (noting " $[\mathrm{t}] \mathrm{he}$ absence of any balancing in the abortion undue burden standard"). See generally Jordan, supra note 91.

97 See Hellerstedt, 136 S. Ct. at 2318 (holding "that the surgical-center requirement, like the admittingprivileges requirement, provides few, if any health benefits for women, poses a substantial obstacle to women seeking abortions, and constitutes an 'undue burden' on their constitutional right to do so"); Planned Parenthood Ariz., Inc. v. Humble, 753 F.3d 905, 912-13 (9th Cir. 2014) ("The more substantial the burden, the stronger the state's justification for the law must be to satisfy the undue burden test; conversely, the stronger the state's justification, the greater the burden may be before it becomes 'undue.' ... [W] e must weigh the burdens against the state's justification, asking whether and to what extent the challenged regulation actually advances the state's interests. If a burden significantly exceeds what is necessary to advance the state's interests, it is 'undue."'); Planned 
Still, Casey's outright balancing is categorically different from the fit analysis mandated by the tiers of scrutiny. The scrutiny tiers do not ask courts to weigh the costs and benefits of the law; they ask instead whether the state interest meets the threshold level of importance as an absolute matter, and if so whether the law is adequately tailored to that interest. ${ }^{98}$ Although the scrutiny tiers had their origins in judicial balancing, "[o]ver time ... the Court worked to shut down the interest balancing internal to these standards, such that the outcome of rational basis review, and strict scrutiny, became practically a foregone conclusion." 99 Casey was a self-conscious attempt to do something different. "The 'undue burden' standard in abortion cases is [a] doctrinal device introduced to allow some latitude for balancing in a field of law previously governed by a rigid tiered review standard."100 Casey's costs/benefits balancing and the means/ends fit analysis of the tiers of scrutiny are thus two entirely different animals.

In sum, if we are going to make sense of the purpose prong in the undue burden analysis, we need to begin by purging the tiers of scrutiny from the discourse. The purpose prong is not a direct analog of any aspect of a scrutiny inquiry or of any of the various roles that purpose plays in the tiered scrutiny regime. The tiers are simply not relevant and invoking them only serves to confuse things. Again, undue burden is not a level of scrutiny. It is something else entirely - a different sort of a constitutional test, which is hardly unheard of in constitutional law. There are many areas of constitutional law that are governed by doctrinal tests unrelated to the tiers of scrutiny.

Consider, for instance, the Establishment Clause - which the courts enforce with a tangled web of assorted doctrinal tests, none of which are the tiers of

Parenthood of Wis., Inc. v. Van Hollen, 738 F.3d 786, 798 (7th Cir. 2013) ("The feebler the medical grounds, the likelier the burden, even if slight, to be 'undue' in the sense of disproportionate or gratuitous.”); cf. Planned Parenthood of Se. Pa. v. Casey, 505 U.S. 833, 878 (1992) (plurality opinion) ("Unnecessary health regulations that have the purpose or effect of presenting a substantial obstacle to a woman seeking an abortion impose an undue burden on the right." (emphasis added)).

98 See Jud Mathews \& Alec Stone Sweet, All Things in Proportion? American Rights Review and the Problem of Balancing, 60 EMORY L.J. 797, 844, 846 (2011) (noting that often "the judge performs the compelling interest inquiry without serious consideration of the right, or balancing," with "deafening silence on the question of whether the government's interest did or did not outweigh" the individual's right).

99 Id. at 837; see also Bhagwat, supra note 48, at 311 \& n.48 (asking "[h]ow ... judicial 'balancing' of individual rights against governmental or public interests fit[s] within the Court's current doctrinal framework," and concluding that "the three-tiered jurisprudence that dominates the individual rights area" "does not appear to contemplate any balancing in most contexts"); $f$. Fallon, supra note 31, at 79 ("There is, undoubtedly, a sense in which these tests could count as balancing tests. [Strict scrutiny and rational basis review] require courts to assess whether a statute ought to be upheld, in light of the government interests that it serves, despite its impact on constitutionally protected values. Nonetheless, more illumination is lost than gained by failing to distinguish relatively even-handed balancing tests, on one hand, from suspect- and nonsuspect-content tests, on the other[, especially given that strict scrutiny is usually fatal in fact, and rational basis is usually a rubber stamp]."). 
scrutiny. ${ }^{101}$ Indeed, the Establishment Clause is a particularly good exemplar, because its principal test - the Lemon test ${ }^{102}$ - bears salient resemblance to the undue burden inquiry in one significant respect. With each test, either an improper purpose or an impermissible effect is, independently, sufficient to render a law unconstitutional, without need for a means/ends fit analysis of the type undertaken pursuant to the tiers of scrutiny. Of course, the Lemon test has its detractors, just as the undue burden test does. ${ }^{103}$ The point here is simply that the Lemon test is conceptually quite simple to understand and has nothing to do with the tiers of scrutiny. And neither does the undue burden test.

\section{What Does the Purpose Prong PROHIBIT?}

Divorcing the purpose prong from the tiers of scrutiny, and treating it instead as an independent doctrinal entity, starts us off on a clean slate. But we still have quite a bit of work to do to figure out what, if anything, the prong actually means.

Making sense of the purpose prong requires us to wrestle with the conceptual problem identified at the outset of the Article - if the state is allowed to act with the purpose of protecting fetal life, then how can any abortion restriction ever lack a permissible purpose?

\section{A. Perhaps There Is No Purpose Prong}

Let us begin by considering the possibility that this problem is intractable. Perhaps the purpose prong is hopelessly incoherent at its core- so much so that we ought to, or perhaps have no choice but to, give up on it altogether. ${ }^{104}$

101 See Erwin Chemerinsky, The Parsonage Exemption Violates the Establishment Clause and Should Be Declared Unconstitutional, 24 WHITTIER L. REV. 707, 721 (2003) (explaining that there is "no agreement . . a as to the test to be used in Establishment Clause cases," and summarizing the various tests the Court has employed).

102 See Lemon v. Kurtzman, 403 U.S. 602, 612-13 (1971) ("First, the statute must have a secular legislative purpose; second, its principal or primary effect must be one that neither advances nor inhibits religion, [and] finally, the statute must not foster an excessive government entanglement with religion." (citations and internal quotation marks omitted)).

103 In each case, the most memorably vocal detractor has been Justice Scalia. See Lamb's Chapel v. Ctr. Moriches Union Free Sch. Dist., 508 U.S. 384, 398 (1993) (Scalia, J., concurring) ("Like some ghoul in a late-night horror movie that repeatedly sits up in its grave and shuffles abroad, after being repeatedly killed and buried, Lemon stalks our Establishment Clause jurisprudence once again, frightening the little children and school attorneys ....”); Planned Parenthood of Se. Pa. v. Casey, 505 U.S. 833, 987 (1992) (Scalia, J., dissenting) ("The ultimately standardless nature of the 'undue burden' inquiry is a reflection of the underlying fact that the concept has no principled or coherent legal basis.").

104 Of course, there are those who criticize all efforts to identify wrongful legislative purpose. See, e.g., Fallon, supra note 44, at 527 (noting the deep "doctrinal and conceptual" difficulties with purpose scrutiny); K.G. Jan Pillai, Shrinking Domain of Invidious Intent, 9 WM. \& MARY BILL RTS. J. 525, 530 (2001) ("It is almost impossible to detect, sort out, and quantify the motives of individual legislators who vote for legislation on the basis of their own disparate beliefs, values, interests, and 
Casey makes crystal clear that a purpose to protect unborn life is not invalid. The joint opinion obsessively drills this point home again and again, insisting that the state may engage in "regulation aimed at the protection of fetal life" - may enact "law [s] designed to further the State's interest in fetal life."105 This is so, the Court says, because "the State has legitimate interests from the outset of the pregnancy in protecting ... the life of the fetus that may become a child." 106 The undue burden test is built on the proposition that "[ $[\mathrm{t}] \mathrm{he}$ woman's liberty is not so unlimited ... that from the outset the State cannot show its concern for the life of the unborn."107 Indeed, the plurality explains that Roe's failure to give sufficient weight to that state interest is the primary reason why Casey rejects Roe's strict scrutiny test and trimester framework. ${ }^{108}$

But, of course, all restrictions on abortion are motivated by these "prolife" concerns. 109 That is the conceptual conundrum that suggests that the purpose prong is a nullity. ${ }^{110}$

circumstances. It is inaccurate to suggest that there is an ascertainable, unequivocal motivation of the legislature; invariably, legislators are motivated by different reasons even while voting for the same law. Therefore, one who searches for the invidious ... intent of a legislature may well end up 'trying to prove something that may be non-existent."'); Cass R. Sunstein, Interest Groups in American Public Law, 38 Stan. L. REv. 29, 77 (1985) ("Even individual legislators almost always act on the basis of mixed motivations. Conceptions of the public good and the desire to be reelected are inseparably intertwined. The problem becomes truly intractable when the issue is the 'motivation' of a multimember decisionmaking body. In such circumstances, the notion of motivation becomes incoherent; another basis for analysis is necessary.”). But those arguments have largely fallen on deaf ears. Today, purpose scrutiny plays a central role in protecting a wide range of constitutional rights and values, including, among many others, equal protection, free speech, freedom from established religion, and free exercise of religion. See McCreary Cty. v. ACLU, 545 U.S. 844, 861 (2005) (noting that "governmental purpose is a key element of a good deal of constitutional doctrine"); Fallon, supra note 31, at 90-98 (listing many areas of constitutional law in which purpose analysis plays an important role); Caleb Nelson, Fudicial Review of Legislative Purpose, 83 N.Y.U. L. REV. 1784, 1786 (2008) ("Under the orthodox modern view, attempts to unearth the actual purposes behind legislation are a widely accepted part of the practice of judicial review."); Richard H. Pildes, Avoiding Balancing: The Role of Exclusionary Reasons in Constitutional Law, 45 HASTINGS L.J. 711, 714 (1994) (arguing that purpose review accounts for a surprisingly large portion of all constitutional doctrine); Ristroph, supra note 45, at 1384 ("Despite the occasional complaints, government motives continue to drive much of constitutional doctrine.").

105 Casey, 505 U.S. at 873, 877 (plurality opinion).

106 Id. at 846 (majority opinion); see also Gonzales v. Carhart, 550 U.S. 124, 145 (2007) (reiterating that a "premise central" to "the Casey joint opinion" is "that the government has a legitimate and substantial interest in preserving and promoting fetal life"); Casey, 505 U.S. at at 871 (plurality opinion) (sanctioning "the interest of the State in the protection of potential life").

107 Casey, 505 U.S. at 869.

108 See id. at 871,875 .

109 See, e.g., CHEMERINSKy, supra note 34, at 850 ("Every law adopted to limit abortion is for the purpose of discouraging abortions and encouraging childbirth.").

110 This is Justice Thomas' view. See Stenberg v. Carhart, 530 U.S. 914, 1008 n.19 (2000) (Thomas, J., dissenting) (asserting that any effort to find a law "unconstitutional because it has the purpose of imposing an undue burden" would be "squarely inconsistent with Casey, which stated that States may enact legislation to "express profound respect for the life of the unborn"' (quoting Casey, 505 U.S. at 877 (plurality opinion)) (citing dicta in Mazurek v. Armstrong, 520 U.S. 968, 972 (1997) 
Perhaps we can save the purpose prong by recasting its operative question more narrowly as whether or not the state was motivated by a purpose to impose an undue burden on the woman's exercise of her constitutional rights. But, subjectively anyway, that will never be the case. If the legislators disagree with Roe v. Wade, and believe that life begins at conception, then obviously they do not think that any burden on abortion rights is undue. When balancing the costs and benefits of the law, they believe that the woman's interest in privacy and autonomy must always yield to the fetus' paramount interest in life (unless perhaps the woman's own life is at risk). From the legislators' perspective, no burden on her right, imposed to save the fetal life, is an undue one - which means that the legislature never acts with the purpose of imposing an undue burden. So again, the purpose prong is a nullity.

Of course, that problem can be avoided by insisting that the question is whether the legislature had the purpose to impose a burden that the law treats as objectively undue, even if the legislators themselves subjectively do not agree. And the measure for whether a burden is objectively undue is whether or not it imposes a substantial obstacle. In Casey's words, the question is whether the "regulation has the purpose ... of placing a substantial obstacle in the path of a woman seeking an abortion of a nonviable fetus."111

But does the legislature ever have such a purpose? The states are not enacting these laws with the purpose of imposing obstacles in the path of women. One generally does not impose an obstacle for the sake of imposing an obstacle - just to be a jerk. The obstacle is simply a means to an end. One imposes an obstacle in the path of another because one has a reason to try to prevent the other from moving forward. It is that reason that constitutes the purpose for the law. In the abortion context, the ultimate end - the reason for imposing the obstacle, and the true purpose behind the law - is to protect unborn life. Which, again, Casey emphatically declares to be a permissible one.

So we are back to square one.

At the end of the day, we are left with the nagging sense that this really is not a purpose question at all. Casey asserts that the state cannot have a purpose to protect unborn life by imposing substantial obstacles in the path of the woman. ${ }^{112}$ But that is a means question, not an ends question, as Casey itself seems to admit when it uses the confusing means language discussed earlier: "A statute with this purpose is invalid because the means chosen by the State to further the interest in potential life must be calculated to inform the

(per curiam) (expressing doubt about the existence of the purpose prong))).

111 Casey, 505 U.S. at 877 (plurality opinion).

$112 I d$. 
woman's free choice, not hinder it."113 The ends are fine. The purpose is fine: protecting life. But the means to get there are not.

If this is correct - if the question is really one of means, not ends - then the issue is really one of effect, rather than purpose. The state is allowed to pursue this goal - to act with this purpose. It is just not allowed to do so in this particular way, because of the excessive harm that this particular method of proceeding imposes on women. Which suggests that the purpose prong does not really exist.

Reducing the undue burden test to its bare essence, the state has an interest in protecting potential life, and the woman has an interest in reproductive freedom. Those two interests have to be balanced, and the state cannot pursue its interest to the point of unduly burdening the woman's interest. It is not the state's goal that is the problem. It is, instead, the infringement of rights that comes when the state pursues that goal too aggressively. As such, the balancing test of the effects prong is all that there really is to the undue burden test.

This is exactly how Justice Scalia interpreted the test in his Casey dissent. He bemoaned that the plurality "cannot possibly mean what it says. Any regulation of abortion that is intended to advance what the joint opinion concedes is the State's 'substantial' interest in protecting unborn life will be calculated to hinder a decision to have an abortion."114 Thus, the state's purpose will always be permissible, and will never be dispositive. Rather, the results of the undue burden test will always turn on the balancing conducted under the effects prong, which yields the seemingly absurd conclusion that "the joint opinion permits the State to pursue that [valid] interest only so long as it is not too successful." 115

If this is correct, then Casey's purpose prong is both incoherent and irrelevant. ${ }^{116}$ We have to consider the possibility that it was just the sloppy work of three co-authors, each with very different views of the law, shooting from

113 Id.; cf. Brownstein, supra note 41, at 882 (noting that the "joint opinion's use of the term 'substantial obstacle' may have contributed to the ... confusion, since that expression would most typically be used to describe an effects test" rather than an examination of legislative purpose).

114 Casey, 505 U.S. at 986-87 (Scalia, J., dissenting) (internal quotation marks and brackets omitted).

115 Id. at 992.

116 See, e.g., Khiara M. Bridges, Capturing the Fudiciary: Carhart and the Undue Burden Standard, 67 WASH. \& LEE L. REV. 915, 921 (2010) (arguing that, since the purpose prong "presupposes the existence of a valuable fetal 'life,' it is likely that any legislation aimed at protecting that 'life' will pass constitutional muster"); Jarrard, supra note 24, at 483 ("[G]iven the breadth of permissible purposes for the regulation of abortion - protecting maternal health and respect for prenatal life - a court can nearly always interpret the regulation to have a constitutional purpose ...."); id. at 488 ("[]n the particular context of abortion jurisprudence and the undue burden standard, judicial inquiry into legislative purpose has been an ineffective tool for protecting women's right to choose because the permissible purposes enunciated by the Supreme Court have become so all-encompassing that a proper legislative purpose is practically assumed.”). 
the hip on a tight deadline, ${ }^{117}$ and struggling quixotically to find a middle ground in an area that necessarily calls for absolutes. ${ }^{118}$ Perhaps it is just jumbled doctrine hastily crafted and ill conceived. ${ }^{119}$ Too many cooks spoil the broth, especially when they are cooking without a recipe, in a great rush, and naively seeking to make a soup that will somehow magically appeal to all palates simultaneously.

If all of this is right, then courts and commentators have actually been wise to ignore or disparage the purpose prong all of these years.

\section{B. But Really There Is}

But I do not believe that it is right. Casey articulates a two-pronged test. We cannot simply ignore one of the prongs unless there is truly no way to make any sense of it. Nor can we accept a claim that, since Casey infused its brief discussion of purpose with the notion of means - "[a] statute with this purpose is invalid because [of] the means chosen by the State"120 - the purpose language was really just an awkward description or elaboration of the effects prong, rather than an articulation of a separate path to unconstitutionality. There is simply no way to torture that meaning out of the Court's language. Whatever Casey may have been trying to accomplish when it confusingly used means language to discuss legislative purpose, it was clearly not referencing the balancing of costs and benefits that takes place under the effects prong. ${ }^{121}$ And it was not clumsily invoking a typical means inquiry. Typically, when courts analyze means in evaluating constitutionality, they are deciding how much collateral damage to constitutional norms they will allow the state to impose in the course of its efforts to achieve a permissible end. The means inquiry is a question of how closely we require the state to tailor its law to its permissible purpose. ${ }^{122}$ If the law can survive the separate ends inquiry, then the state is

117 See JeFFrey ToObin, The Nine: Inside THE SECRET WORLD OF THE SUPREME COURT 47-59 (2007) (describing the process by which Justices Souter, O'Connor, and Kennedy came together at the last minute to try to salvage the core of Roe); $i d$. at 56 ("Through its many drafts, the troika's opinion had become somewhat disorganized and confusing.").

118 See, e.g., Caitlin E. Borgmann, Abortion, the Undue Burden Standard, and the Evisceration of Women's Privacy, 16 WM. \& MARY J. WOMEN \& L. 291, 291 (2010) (arguing that the plurality was "trying to strike an impossible compromise").

119 Cf. Michael C. Dorf, Incidental Burdens on Fundamental Rights, 109 HARV. L. REv. 1175, 1233 (1996) (noting the "sloppy language on the part of the three authors" in the joint opinion of Casey).

120 Casey, 505 U.S. at 877 (plurality opinion).

121 Cf. Khiara M. Bridges, "Life" in the Balance: Fudicial Review of Abortion Regulations, 46 U.C. DAVIS L. REV. 1285, 1314-15 (2013) (noting "that the 'purpose prong' of the undue burden standard has fallen by the wayside" such that "[a]ll that is left is an inquiry into effects," and that the "undue burden standard ... incorporate[s] balancing into ... [that] effects test").

122 See Ian Ayres, Narrow Tailoring, 43 UCLA L. REv. 1781, 1786 (1996) ("The idea that a remedy needs to be tailored to further the government's legitimate interest is unexceptional - and is captured by the idea that remedial classifications should not be too overinclusive or underinclusive."); Matthew 
permitted to achieve the ends it seeks; the means question asks simply whether the law could have been crafted more precisely so as to achieve those ends without doing as much violence to the constitutional norm that it threatens.

But, under Casey, the state is not allowed to ensure the protection of all unborn life. That is an end that the state is not permitted to achieve. The state is allowed to try to protect all unborn life; but it is not allowed to succeed. This is what Justice Scalia found to be so incomprehensible about the undue burden standard. ${ }^{123}$ A law that was perfectly tailored to the permissible goal of protecting fetal life - a law that effectively prohibited all abortions, and therefore saved all fetuses, but did nothing more, and thus was not over- or under-inclusive in any way - would be patently unconstitutional under Casey.

Something else besides a means inquiry is going on here; Casey's discussion of purpose is not simply a muddled discussion of means. Rather, when Casey talks about legislative purpose, it must really be talking about legislative purpose. The purpose prong must really be an ends question, not a means question.

And, this Article submits, it is not an incoherent one. We can solve the conceptual problem; we just have to recognize that it is tied up in an abstraction problem. Constitutional purpose inquiries cannot avoid wrestling with the question of the proper level of generality at which to articulate the state interest or governmental purpose. ${ }^{124}$ At a high enough level of abstraction, all laws were enacted for a permissible purpose. What legislator could not say with a straight face that she voted for a law in order to make the world a better place? Yet meaningful purpose inquiries still pervade constitutional law. ${ }^{125}$ We are left to struggle to determine the proper level of generality at which to conduct them. ${ }^{126}$ As Ely once wrote,

\footnotetext{
D. Bunker \& Emily Erickson, The Furisprudence of Precision: Contrast Space and Narrow Tailoring in First Amendment Doctrine, 6 COMM. L. \& POL'Y 259, 260 (2001) ("One thing these tests and their various 'narrow tailoring' components require is that judges envision possible alternatives to the regulation at hand to determine if there are less restrictive means of achieving the government's purpose."). values and officials' motivations. For example, a statute will fail scrutiny under the Establishment Clause if its purpose is to promote religion. According to a leading case, a state legislature offended this prohibition when it enacted a statute barring the teaching of evolution in the public schools. This ascription would probably stand even if those enacting the restriction could accurately report that their motive was not to promote religion, but to stop the communication of ideas that they believed to be educationally unsuitable (because false), or to please their constituents, or to win re-election. As implemented by a purpose test, the First Amendment precludes action on otherwise permissible considerations (such as pleasing constituents or trying to win re-election) when those reasons, in a
} 
[W]e all know how to play House That Jack Built: he voted for the bill authorizing the redrawing of school district lines in order to bring about its passage, and thereby to permit the school boards to redraw the lines so as to separate white and black neighborhoods in order to segregate the schools so as to keep the races apart, thus avoiding miscegenetic marriages, thereby diminishing the possibility of his daughter's marrying a Negro . . . . The crucial question is how one decides at which point on the continuum [the relevant legislative] purposes [lie]. ${ }^{127}$

We can play the same game here: He voted for the bill to impose additional regulations on abortion providers in order to bring about its passage, and thereby to make abortion clinics more costly to run, thus increasing the cost of abortions and forcing many of the clinics out of business, thereby reducing the affordability and availability of abortions, thus reducing the prevalence of abortion, in order to protect unborn life.

What is the proper level of generality at which to articulate the purpose behind abortion regulations? Should we be considering a broader, ultimate purpose behind the law (such as protecting fetal life), or some sort of narrower, more immediate purpose (such as shutting down abortion clinics)?

Let us go back to Casey's key language again, this time with an eye towards the abstraction issue. When we do so, we can see that Casey is, in fact, answering the abstraction question for us:

A finding of an undue burden is a shorthand for the conclusion that a state regulation has the purpose or effect of placing a substantial obstacle in the path of a woman seeking an abortion of a nonviable fetus. A statute with this purpose is invalid because the means chosen by the State to further the interest in potential life must be calculated to inform the woman's free choice, not hinder it. And a statute which, while furthering the interest in potential life or some other valid state interest, has the effect of placing a substantial obstacle in the path of a woman's choice cannot be considered a permissible means of serving its legitimate ends. ${ }^{128}$

What, exactly, is the ends question that the Court is asking here? Garbled as this passage may be, I think that we can discern an answer.

The Court is not asking the state, "Why did you enact this law?" The likely answer to that question would be, "To protect unborn life" - a perfectly fine answer under Casey, to be sure. But that is not the question. The Court is instead asking, "Why did you choose this particular means to protect unborn life? Why did you seek to do it in this way - with this regulationrather than in another way?"

That is the real question being asked by Casey's purpose inquiry. The answer to that question cannot be, "To protect unborn life." That answer is

particular case, are too conceptually or practically interconnected with constitutionally forbidden grounds for official action.

Fallon, supra note 31, at 71 (footnotes omitted).

127 Ely, supra note 44, at 1219.

128 Planned Parenthood of Se. Pa. v. Casey, 505 U.S. 833, 877 (1992) (plurality opinion). 
non-responsive. "Yes," the Court might retort, "we know that you are trying to protect unborn life. And that is fine, as far as it goes. But why did you choose to do it in this way?"

That is the question that requires an answer under the purpose prong. It is a more precise question, and it therefore calls for answers articulated at a narrower level of generality. Protecting fetal life will no longer do. It is true that the Court is asking about means, rather than ultimate ends. But it is seeking to ascertain the purpose behind the choice of means, not whether an illsuited means suggests that the state is lying about the true ends, or whether more carefully tailored means could accomplish the same ends without imposing as much collateral damage. The state may pursue its ultimate end, but it may not make the choice among possible means of doing so for improper reasons. ${ }^{129}$

Consider an analogy to voting rights. In some areas of voting rights law, a "flexible standard applies." 130 Under that standard,

A court considering a challenge to a state election law must weigh "the character and magnitude of the asserted injury to the rights protected by the First and Fourteenth Amendments that the plaintiff seeks to vindicate" against "the precise interests put forward by the State as justifications for the burden imposed by its rule," taking into consideration "the extent to which those interests make it necessary to burden the plaintiff's rights." 131

This test, while not identical to Casey's undue burden test, is certainly analogous. ${ }^{132}$ Indeed, the Casey plurality itself explicitly drew the analogy. ${ }^{133}$ And courts often refer to this test as an "undue burden" test. ${ }^{134}$ Let us imagine that this test was even more comparable to Casey and had been interpreted to include a purpose prong similar to Casey's - to preclude any regulation that

129 Long before the Court's decision in Casey, Eric Schnapper identified this category of wrongful governmental intent: an improper purpose in choosing the means by which to achieve permissible ends. See Eric Schnapper, Two Categories of Discriminatory Intent, 17 HARV. C.R.-C.L. L. REV. 31, $37-38$ (1982).

130 Burdick v. Takushi, 504 U.S. 428, 433-34 (1992).

131 Id. at 434 (quoting Anderson v. Celebrezze, 460 U.S. 780, 789 (1983)).

132 See, e.g., Kelly E. Brilleaux, The Right, the Test, and the Vote: Evaluating the Reasoning Employed in Crawford v. Marion County Election Board, 70 LA. L. REV. 1023, 1057 (2010) (noting that the Burdick test "parallels the undue burden standard set forth in Planned Parenthood v. Casey").

133 See Casey, 510 U.S. at 873-74 (plurality opinion) ("As our jurisprudence relating to all liberties save perhaps abortion has recognized, not every law which makes a right more difficult to exercise is, ipso facto, an infringement of that right. An example clarifies the point. We have held that not every ballot access limitation amounts to an infringement of the right to vote. Rather, the States are granted substantial flexibility in establishing the framework within which voters choose the candidates for whom they wish to vote." (citing Norman v. Reed, 502 U.S. 279 (1992); Celebrezze, 460 U.S. at 788)).

134 See, e.g., Fla. State Conference of NAACP v. Browning, 522 F.3d 1153, 1183 (11 th Cir. 2008) (evaluating whether a law "places an undue burden on the right to vote"); Crawford v. Marion Cty. Election Bd., 472 F.3d 949, 950, 952 (7th Cir. 2007) (deciding whether a voting restriction imposed an undue "burden on the right to vote"), aff d, 553 U.S. 181 (2008). 
has the purpose or effect of placing a substantial obstacle in the path of a citizen seeking to vindicate the right to vote. ${ }^{135}$

In defending against a purpose challenge to a statute that burdens voting rights, legislators could virtually always honestly claim that the reason why they imposed the restriction was to preserve their incumbency - to maximize their chances of getting reelected. That is a perfectly valid purpose. There is nothing wrong with politicians seeking to win elections. ${ }^{136}$

But of course, that answer would not do. The operative purpose question would be a more narrow one: "Why did you choose to use this means - this particular voter identification requirement, or decision to cut back on early voting, or what have you - as the way to try to ensure your reelection?" If the truthful answer to that question is, "Because we thought that this regulation would make it harder for voters who are likely to support our opponents to vote," then the legislature acted with an improper purpose to place a substantial obstacle in the path of citizens seeking to vote.

The same reasoning applies here. The operative question under Casey's purpose prong is one posed at a narrower level of abstraction: "Why did you choose this particular means to try to protect potential life (or some other valid state interest)?"137

The next step in the analysis is to figure out which answers are permissible and which are impermissible - and, more importantly, why.

\section{Permissible Purposes}

Let us begin by briefly listing the purposes (behind the choice of means) that the Supreme Court, in Casey and its progeny, has told us are permissible.

135 In fact, the Burdick/Celebrezze test does not seem to contain a potent purpose prong. Courts do not inquire into the actual purpose behind the voting restrictions. See Crawford v. Marion Cty. Election Bd., 553 U.S. 181, 191 (2008) ("While petitioners argue that the statute was actually motivated by partisan concerns and dispute both the significance of the State's interests and the magnitude of any real threat to those interests, they do not question the legitimacy of the interests the State has identified."). For an argument that courts should consider purpose in this context, see Richard H. Pildes, The Supreme Court, 2003 Term - Foreword: The Constitutionalization of Democratic Politics, 118 HARV. L. REV. 28, 76, 83, 139 (2004).

136 See Deborah Hellman, Defining Corruption and Constitutionalizing Democracy, 111 MiCH. L. REv. 1385, 1412 (2013) ("Of course, legislators legitimately try to get reelected, and their desire to do so, at least on many accounts, is a proper motive influencing their decisions.").

137 Cf. Brownstein, supra note 41, at 883 ("It is critical to understand here that the plurality is extending an examination of the state's purpose to include both the state's goal and the means by which that goal is to be furthered. Thus, the state's ultimate goal of protecting potential life, in the abstract, is a constitutionally legitimate one. However, the state cannot attempt to further that goal by substituting its choice favoring birth over abortion for the choice of the woman by deliberately hindering her ability to effectuate a contrary decision and obtain an abortion."). 


\section{a. "to inform the woman's free choice"138}

Casey insists that "the State is [not] prohibited from taking steps to ensure that this choice is thoughtful and informed."139 In particular, the state is permitted to act with the purpose of making sure that the woman is aware, before she makes her choice, of what, exactly, happens to the fetus in an abortion procedure. ${ }^{140}$

\section{b. "to persuade her to choose childbirth over abortion"141}

Casey is quite explicit and insistent in explaining that the state need not be a neutral informant when it pursues its interest in informed consent. Instead, the state may actively "attempt[] to influence a woman's decision on behalf of the potential life within her." 142

To promote the State's profound interest in potential life, throughout pregnancy the State may take measures to ensure that the woman's choice is informed, and measures designed to advance this interest will not be invalidated as long as their purpose is to persuade the woman to choose childbirth over abortion. ${ }^{143}$

Put differently, the state is permitted to try to discourage the woman from exercising her right to an abortion. ${ }^{144}$

\section{c. to protect the woman from the psychological consequences of coming to regret her decision in the future ${ }^{145}$}

"In attempting to ensure that a woman apprehend the full consequences of her decision, the State furthers the legitimate purpose of reducing the risk

138 Casey, 505 U.S. at 877 (plurality opinion).

139 Id. at 872; see also Gonzales v. Carhart, 550 U.S. 124, 159 (2007) ("The State has an interest in ensuring so grave a choice is well informed.").

140 See Casey, 505 U.S. at 873 (plurality opinion) (approving of "[m] easures aimed at ensuring that a woman's choice contemplates the consequences for the fetus"); see also Gonzales, 550 U.S. at 159 ("It is, however, precisely this lack of information concerning the way in which the fetus will be killed that is of legitimate concern to the State.").

141 Casey, 505 U.S. at 878 (plurality opinion).

142 Id. at 876; see also id. at 883 (explaining that the state may "enact[] legislation aimed at ensuring a decision that is mature and informed, even when in so doing the State expresses a preference for childbirth over abortion").

143 Id. at 878; see also id. at 872-73 (explaining that an "inevitable consequence of our holding that the State has an interest in protecting the life of the unborn" is that "the State may enact rules and regulations designed to encourage her to know that there are philosophic and social arguments of great weight that can be brought to bear in favor of continuing the pregnancy to full term").

144 See id. at 882 (rejecting the notion that the state may not mandate the provision of "information ... designed to dissuade the woman from having an abortion"). 
that a woman may elect an abortion, only to discover later, with devastating psychological consequences, that her decision was not fully informed."146

\section{d. "to foster the health of a woman seeking an abortion"147}

"As with any medical procedure, the State may enact regulations to further the health or safety of a woman seeking an abortion." 148 It usually makes sense to view the desire to protect women's health as a permissible purpose entirely distinct from the desire to protect fetal life, rather than as a reason for choosing particular means to advance the latter interest. ${ }^{149}$ But sometimes, it can be difficult to separate the two. A state seeking to protect fetal life might, for instance, defend a mandate that women be provided with information designed to discourage them from choosing abortions on the ground that this information will help them avoid undergoing a dangerous and harmful medical procedure. ${ }^{150}$ In other words, protecting women's health might be the reason (or one of the reasons) why the state chose to protect fetal life in this particular way. Similarly, pro-life advocates believe that, when women who have abortions get pregnant in the future, complications from the earlier abortion can pose risks to the pregnancy and to the life and health of the subsequent fetus. ${ }^{151}$ Protecting women from those health complications will thus, in their minds, ultimately protect fetal life.

\section{e. to facilitate medical research 152}

In Casey, the Court upheld several "recordkeeping and reporting provisions" because they "relate to health" and are "a vital element of medical research." 153

146 Id.; see also Gonzales, 550 U.S. at 159-60 ("It is self-evident that a mother who comes to regret her choice to abort must struggle with grief more anguished and sorrow more profound when she learns, only after the event, what she once did not know ....”).

147 Casey, 505 U.S. at 878 (plurality opinion).

$148 \quad I d$.

149 See id. at 846 (majority opinion) (asserting that "the State has legitimate interests from the outset of the pregnancy in protecting the health of the woman and the life of the fetus that may become a child").

150 Pro-life advocates routinely assert that abortion is harmful to women's health. See infra note 196.

151 See Anna Paprocki, Ten Years of Defending Life: AUL Educates Americans on Abortion's Harm to Women, in DefENDing Life 2015: CeLebrating Ten YeARs of DefENDing Life, supra note 7, at 29, 31.

152 Casey, 505 U.S. at 900-01 (plurality opinion).

153 Id. This purpose, too, could also be thought of as a separate primary purpose, or perhaps as a reason for choosing particular means of protecting women's health. 


\section{f. "to promote respect for life, including life of the unborn" 154}

In Gonzales, the Court declared that " $[\mathrm{t}]$ he government may use its voice and its regulatory authority to show its profound respect for the life within the woman."155 That is to say, the state may act with the purpose of "express[ing] respect for the dignity of human life."156

\section{g. to "protect[] the integrity and ethics of the medical profession"157}

In Gonzales, the Court upheld a federal ban on a particular type of abortion procedure in part because that "brutal" procedure allegedly "undermines the public's perception of the appropriate role of the physician during the delivery process." 158

\section{Impermissible Purposes}

Now let us briefly list the purposes (behind the choice of means) that the Court has made clear are impermissible.

Id.

Id. (citation and internal quotation marks omitted).

58 Id. at 160 (citation and internal quotation marks omitted). One might question whether the interests upheld in Gonzales - promoting respect for life and protecting the integrity of the medical profession - are better understood as separate primary purposes, rather than as valid reasons for choosing particular means of advancing the primary interest in protecting fetal life. After all, as Justice Ginsburg pointed out in her Gonzales dissent, a ban on a particular kind of abortion procedure "scarcely furthers" the "interest of the Government in protecting the life of the fetus that may become a child": "[ $\mathrm{t}$ ] he law saves not a single fetus from destruction, for it targets only a method of performing abortion." Id. at 181 (Ginsburg, J., dissenting) (citation and internal quotation marks omitted). But the Gonzales majority clearly viewed these interests as subordinate ones - as valid reasons for choosing the ban as a means of advancing the ultimate interest in protecting fetal life. The Court explained "the rationale for the congressional enactment": "Implicitly approving such a brutal and inhumane procedure by choosing not to prohibit it will further coarsen society to the humanity of not only newborns, but all vulnerable and innocent human life, making it increasingly difficult to protect such life." Id. at 156-57 (majority opinion) (internal quotation marks omitted) (quoting the congressional findings in 18 U.S.C. $\$ 1531$ (2003)). Thus, "express[ing] respect for the dignity of human life" will help, in the long run, to protect fetal life. Id. at 157. And protecting the integrity and ethics of the medical profession will, in turn, help to express respect for the dignity of life. See $i d$. at 158 (holding that "the State may use its regulatory power to bar certain procedures and substitute others, all in furtherance of its legitimate interests in regulating the medical profession in order to promote respect for life, including the life of the unborn" (emphasis added)). 


\section{a. "to strike at the [abortion] right itself"159}

The law must serve "a valid purpose, one not designed to strike at the right itself." 160 Thus, the state may not act with the intent to undermine or eliminate the right to choose an abortion ${ }^{161}$ —or to provide a vehicle for overturning Roe. ${ }^{162}$

\section{b. to "plac[e] a substantial obstacle in the path of a woman seeking an abortion"163}

The state may not enact a law with the purpose of making it harder for women to get abortions. The regulation cannot "serve [a] purpose ... to make abortions more difficult." 164

$$
\text { c. to "hinder" the "woman's free choice" } 165
$$

Again, "the means chosen by the State to further the interest in potential life must be calculated to inform the woman's free choice, not hinder it."166 The state may not act with the purpose of impeding or thwarting the woman's right to choose an abortion. Wade" does not have a valid purpose); id. (quoting Hope Clinic v. Ryan, 195 F.3d 857, 881 (7th Cir. 1999) (Posner, J., dissenting) (" [] $\mathrm{f}$ a statute burdens constitutional rights and all that can be said on its behalf is that it is the vehicle that legislators have chosen for expressing their hostility to those rights, the burden is undue.”), vacated, 530 U.S. 1271 (2000) (mem.)); Caroline Burnett, Comment, Dismantling Roe Brick by Brick - The Unconstitutional Purpose Behind the Federal Partial-Birth Abortion Act of 2003, 42 U.S.F. L. REV. 227, 230-31 (2007) ("Reliance on the purpose prong is particularly important because behind Congress's medical findings lies a calculated and unconstitutional intent to pass the federal ban as a stepping stone to overturn Roe v. Wade."). cause "the Utah legislature's intent in passing the abortion provisions was to provide a vehicle by which to challenge Roe v. Wade"); see also After Ayotte: The Need to Defend Abortion Rights with Renewed "Purpose," 119 HARV. L. REV. 2552, 2568-71 (2006) (suggesting that courts adopt the Tenth Circuit's approach in Bangerter when assessing whether a law limiting access to abortion was enacted for an invalid purpose).

163 Casey, 505 U.S. at 877 (plurality opinion).

164 Id. at 901 ; cf. Spece, supra note 69 , at 102 ("A desire to protect life by the means of burdening abortion rights is in fact a purpose to burden abortion rights.").

165 Casey, 505 U.S. at 877 (plurality opinion).

$166 I d$. 


\section{d. to misinform or mislead the woman ${ }^{167}$}

Casey held that, in seeking to influence the woman's choice, the government may require "the giving of truthful, nonmisleading information about the nature of the procedure, the attendant health risks and those of childbirth, and the 'probable gestational age' of the fetus." 168 But such a "requirement may be permissible" only if "the information the State requires to be made available to the woman is truthful and not misleading." 169 This strongly implies that the state may not seek to mislead or deceive the woman as she makes her choice. ${ }^{170}$

\section{Putting it All Together}

Again, the operative question under Casey's purpose prong is, "Why did you choose this particular means to try to protect potential life (or to further some other valid interest)?" Permissible answers, which naturally must come at a narrower level of generality, include: "Because we wanted to protect women's health"; and "Because we wanted to discourage women from choosing to end the lives of the fetuses within them." Thus, from a purpose standpoint, there is nothing wrong with laws that were genuinely intended to reduce the risk of harm to the woman from abortion or to encourage women seeking abortions to change their minds.

But impermissible answers include: "Because we wanted to make it harder for women to get an abortion"; and "Because it will help us advance one step closer to our ultimate goal of bringing down Roe v. Wade." The

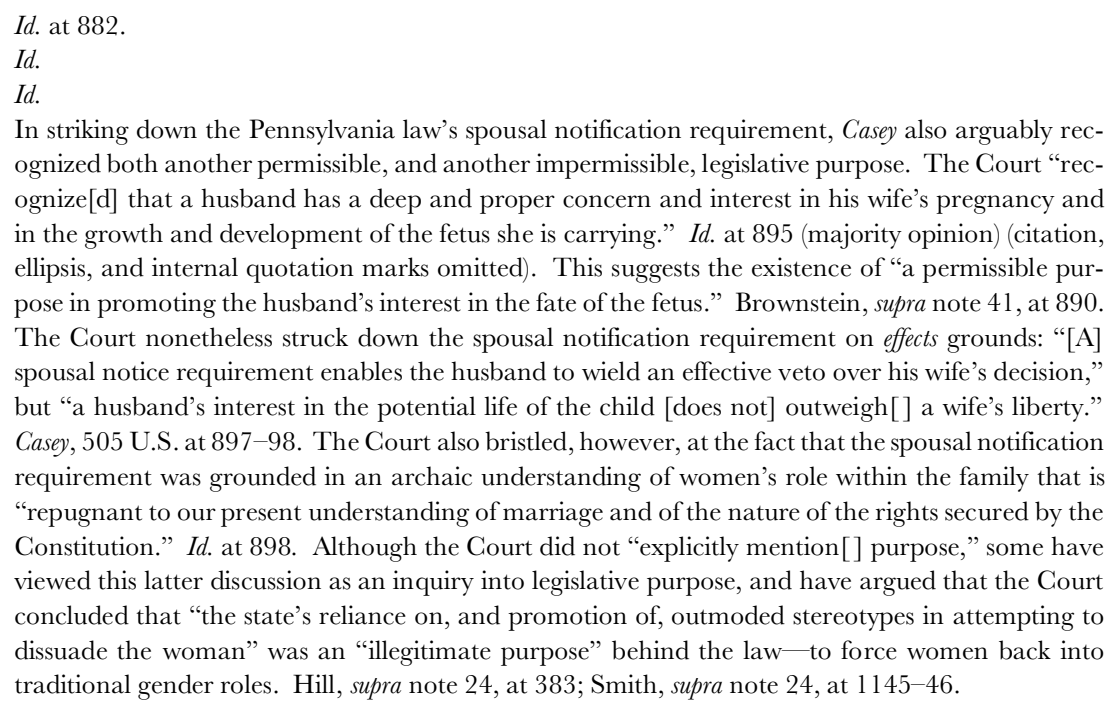
ognized both another permissible, and another impermissible, legislative purpose. The Court "recognize[d] that a husband has a deep and proper concern and interest in his wife's pregnancy and in the growth and development of the fetus she is carrying." Id. at 895 (majority opinion) (citation, ellipsis, and internal quotation marks omitted). This suggests the existence of "a permissible purpose in promoting the husband's interest in the fate of the fetus." Brownstein, supra note 41, at 890. The Court nonetheless struck down the spousal notification requirement on effects grounds: "[A] spousal notice requirement enables the husband to wield an effective veto over his wife's decision," but "a husband's interest in the potential life of the child [does not] outweigh[] a wife's liberty." Casey, 505 U.S. at 897-98. The Court also bristled, however, at the fact that the spousal notification requirement was grounded in an archaic understanding of women's role within the family that is "repugnant to our present understanding of marriage and of the nature of the rights secured by the Constitution." Id. at 898. Although the Court did not "explicitly mention[] purpose," some have viewed this latter discussion as an inquiry into legislative purpose, and have argued that the Court concluded that "the state's reliance on, and promotion of, outmoded stereotypes in attempting to dissuade the woman" was an "illegitimate purpose" behind the law - to force women back into traditional gender roles. Hill, supra note 24, at 383; Smith, supra note 24, at 1145-46. 
former seeks to impose a substantial obstacle and to hinder the woman's free choice; ${ }^{171}$ the latter seeks to strike at the right itself.

The central concept that ties all of this altogether can be summed up in a popular slogan of the pro-life movement: "Choose Life." 172 The state may urge the woman to "choose life," but it has to respect the fact that the choice is the woman's to make, not the state's. The state must respect the woman's choice, even as it seeks to influence it. ${ }^{173}$ Efforts to convince the woman to make a different choice are permissible, but efforts to hinder, impede, or take away the woman's choice are not.

Far from being hopelessly incoherent, this actually makes fundamental sense. ${ }^{174}$ To begin with, it is generally permissible for the government to discourage the exercise of constitutional rights. Consider, for instance, municipal gun buy-back programs, ${ }^{175}$ campaigns to discourage bullying and hate speech in public schools, ${ }^{176}$ plea deals offered to criminal defendants, ${ }^{177}$

171 See Brownstein, supra note 41, at 883 ("Thus, a law requiring five doctors to be present during an abortion procedure for the purpose of dramatically increasing the cost of abortions would be struck down as unduly burdensome, despite the argument that it furthers the state's legitimate purpose of protecting potential life.").

172 See Madsen v. Women's Health Ctr., Inc., 512 U.S. 753, 787 (1994) (Scalia, J., concurring in the judgment in part and dissenting in part) ("Some abortion opponents wear T-shirts bearing the phrase 'Choose Life."').

173 "Choose Life" is generally understood to be a pro-life, rather than a pro-choice, message. See, e.g., Choose Life Ill., Inc. v. White, 547 F.3d 853, 866 n.5 (7th Cir. 2008) (noting that some courts have concluded that it is "viewpoint discrimination to allow a 'Choose Life' specialty [license] plate in the absence of a pro-choice plate.") (emphasis omitted); Alana C. Hake, Note, The States, a Plate, and the First Amendment: The "Choose Life" Specialty License Plate as Government Speech, 85 WASH. U. L. REV. 409, 411 (2007) (stating that "the message 'Choose Life' unequivocally indicates support for the pro-life side of the abortion debate"). But actually, on its own terms, the slogan reads more like a compromise message. To ask a woman to choose life is to recognize that the right to choose is hers, but to seek to influence how she exercises it. See White, 547 F.3d at 867-68 (Manion,J., concurring) ("I disagree with the district court's (and other courts') characterization of the 'choose life' message as simply a pro-life statement. .. The message ... expressly recognizes that it is the woman's choice. But at the same time it recognizes that the life of the developing baby is also at stake."); Scott W. Gaylord, "Kill the Sea Turtles" and Other Things You Can't Make the Government Say, 71 WASH. \& LEE L. REV. 93, 156-57 (2014) ("Through a 'Choose Life' plate, the state is promoting childbirth over abortion, and, in the process, admitting that there is a constitutionally protected choice to be made. States are allowed to do this under ... Casey ....").

174 This is not to say that it is normatively desirable - just that it is conceptually coherent.

175 See Ashley Mata, Comment, Kevlar for the Innocent: Why Modeling Gun Regulation After Great Britain, Australia, and Switzerland Will Reduce the Rate of Mass Shootings in America, 45 CAL. W. INT'L L.J. 169, 20809 (2014) (noting that there have not been Second Amendment challenges to buyback programs).

176 Even the most strident free speech advocates recognize that it would be constitutional for school officials to "encourage[] . . . voluntary self-restraint." Nadine Strossen, Regulating Racist Speech on Campus: A Modest Proposal?, 1990 DukE L.J. 484, 563 (1990) ("[R]egardless of the legal limitations on rules barring hate speech, universities should encourage members of their communities voluntarily to restrain the form of their expression in light of the feelings and concerns of various minority groups.").

177 See Chaffin v. Stynchcombe, 412 U.S. 17, 30 (1973) (noting that the Court has never held "that the Constitution forbids every government-imposed choice in the criminal process that has the effect of discouraging the exercise of constitutional rights[]" and in particular that, through a plea offer, 
and mandatory settlement conferences in civil cases. ${ }^{178}$ But the state is not permitted to coerce the people into giving up their constitutional rights. ${ }^{179}$ And - though there is very little case law on the point - it is a commonly held intuition that the state generally may not act with the purpose of hindering, rather than just discouraging, the exercise of constitutional rights. ${ }^{180}$

And the "Choose Life" concept makes particular sense as an understanding of Casey. The joint opinion in Casey begins by reconfirming "Roe's essential holding." 181 Two key "parts" of that holding are (1) "a recognition of the right of the woman to choose to have an abortion before viability and to obtain it without undue interference from the State," and (2) "the principle that the State has legitimate interests ... in protecting ... the life of the fetus that may become a child." 182 The Court then insists that, as it conceives of them, "[ $\mathrm{t}]$ hese principles do not contradict one another." 183

Why not? Because the abortion right, in Casey's reckoning, is primarily a right of decisional autonomy. ${ }^{184}$ Tying together a long line of cases involving

a defendant may be "dissuaded from exercising his rights to a jury trial and to plead not guilty"that is, each defendant was "“discouraged' from asserting his rights").

178 See FED. R. GIV. P. 16(a)(5) (noting that a district court may order a pretrial conference for the purpose of facilitating settlement).

179 See, e.g., Colorado v. Connelly, 479 U.S. 157, 170 (1986) (holding that the police may not coerce a defendant into waiving his Miranda rights); Brady v. United States, 397 U.S. 742, 750 (1970) (holding that the state may not coerce a defendant into accepting a plea bargain and giving up his Sixth Amendment right to a jury trial); United States v. Ryan, 810 F.2d 650, 656 (7th Cir. 1987) (noting that "the doctrine of unconstitutional conditions precludes the government from coercing the waiver of a constitutional right").

180 See Aleman v. Glickman, 217 F.3d 1191, 1204 n.10 (9th Cir. 2000) (declaring that "a statute whose only purpose is to hinder this right, even if it does not actually, in its effect, interfere directly and substantially with the right to marry, would not be supported by a legitimate government purpose" (citations and internal quotation marks omitted)); Gomillion v. Lightfoot, 270 F.2d 594, 610 (5th Cir. 1959) (Brown, J., dissenting) (declaring that a law cannot stand if its "legislative purpose is to deprive citizens of a state of their constitutional rights"), rev'd, 364 U.S. 339 (1960); 1 LAURENCE H. Tribe, AMERican Constitutional LaW 273 (3d ed. 2000) (asserting that "laws designed to hinder the exercise of constitutional rights are, to that degree, unconstitutional"); $c f .18$ U.S.G. § 241 (criminalizing "conspir[acy] to injure, oppress, threaten, or intimidate any person ... in the free exercise or enjoyment of any right or privilege secured to him by the Constitution").

181 Planned Parenthood of Se. Pa. v. Casey, 505 U.S. 833, 846 (1992).

$182 I d$.

183 Id.; see also Gonzales v. Carhart, 550 U.S. 124, 158 (2007) (insisting that the "premises of Casey must coexist").

184 See Gonzales, 550 U.S. at 172 (Ginsburg, J., dissenting) (noting that "legal challenges to undue restrictions on abortion procedures do not seek to vindicate some generalized notion of privacy; rather, they center on a woman's autonomy to determine her life's course"); Danielle Lang, Truthful But Misleading? The Precarious Balance of Autonomy and State Interests in Casey and Second-Generation DoctorPatient Regulation, 16 U. PA. J. CONST. L. 1353, 1373 (2014) (articulating "the undue burden standard's underlying principle: the protection of women's autonomy"); Reva B. Siegel, Dignity and the Politics of Protection: Abortion Restrictions Under Casey/Carhart, 117 YALE L.J. 1694, 1752 (2008) ("Women's decisional autonomy is a core value the undue burden framework vindicates."). Linda Greenhouse and Reva Siegel have recently published an excellent article explaining Casey as a 
marriage, procreation, and childrearing, ${ }^{185}$ Casey insists that "the Constitution places limits on a State's right to interfere with a person's most basic decisions about family and parenthood." 186 "Our cases recognize the right of the individual, married or single, to be free from unwarranted governmental intrusion into matters so fundamentally affecting a person as the decision whether to bear or beget a child."187 "These matters, involving the most intimate and personal choices a person may make in a lifetime, choices central to personal dignity and autonomy, are central to the liberty protected by the Fourteenth Amendment."188 The abortion right fits squarely into that structure. In Casey's understanding, it is a right of individual choice:

Men and women of good conscience can disagree, and we suppose some always shall disagree, about the profound moral and spiritual implications of terminating a pregnancy, even at its earliest stage.... The underlying constitutional issue is whether the State can resolve these philosophic questions in such a definitive way that a woman lacks all choice in the matter .... 189

Thus, by its own terms, Casey recognizes "[c]onstitutional protection of the woman's decision to terminate her pregnancy."190

What is constitutionally protected, then, is the woman's right to make the ultimate decision - her "right to choose to terminate or continue her pregnancy." 191 That right is protected primarily by Casey's effects prong; in pursuit of its interest in potential life, the state cannot impose obstacles that, in operation, substantially impede the woman's ability to choose, and to implement her choice, to end her pregnancy. But it also has a significant purpose component. The state must respect the woman's individual agency - her autonomy. It can seek to influence her choice, to convince her to "choose life." The state may

$\operatorname{tak}[\mathrm{e}]$ steps to ensure that this choice is thoughtful and informed.... [T]he State may enact rules and regulations designed to encourage her to know that there are philosophic and social arguments of great weight that can be brought to bear in favor of continuing the pregnancy to full term and that there are procedures and institutions to allow adoption of unwanted children as well as a certain degree of state assistance if the mother chooses to raise the child

moderate compromise focused on balancing concerns for fetal life with women's dignity and autonomy. See Greenhouse \& Siegel, supra note 14, at 1434-38.

185 See Casey, 505 U.S. at 851 ("Our law affords constitutional protection to personal decisions relating to marriage, procreation, contraception, family relationships, child rearing, and education.”).

186 Id. at 849.

187 Id. at 851 (emphasis and internal quotation marks omitted).

188 Id.

$189 I d$. at 850.

$190 I d$. at 846 (emphasis added); see also id. at 869 (plurality opinion) (" [] t falls to us to give some real substance to the woman's liberty to determine whether to carry her pregnancy to full term.").

191 Id. at 872-73 (plurality opinion). 
herself. . . . States are free to enact laws to provide a reasonable framework for a woman to make a decision that has such profound and lasting meaning. ${ }^{192}$

But the state has to respect that the choice is the woman's to make; it cannot attempt to deny her the opportunity to decide for herself. It cannot try to trick her, deceive her, or strip away her choice. ${ }^{193}$ It cannot attempt to coerce her into making its preferred choice. Even if the state is acting with the permissible ultimate purpose of protecting fetal life, its choice of means of pursuing that purpose cannot be motivated by any of these desires. ${ }^{194}$

If this is correct, then Justice Scalia was wrong when he argued in his Casey dissent that the joint opinion is incoherent because "[a]ny regulation of abortion that is intended to advance what the joint opinion concedes is the State's 'substantial' interest in protecting unborn life will be calculated to hinder a decision to have an abortion." 195 Such a regulation will surely at least be calculated to affect the decision. But it might not be calculated to hinder it. It might, instead, genuinely be seeking to facilitate and inform the woman's decision. Indeed, much of the rhetoric of the pro-life movement is grounded in the notion that women need to know the truth about abortion, and if we can only succeed in informing them, many will choose not to have abortions. 196 The supporters of these laws insist that, as a result of these

192 Id.; see also Jeremy A. Blumenthal, Abortion, Persuasion, and Emotion: Implications of Social Science Research on Emotion for Reading Casey, 83 WASH. L. REV. 1, 11 (2008) (noting that Casey permits the provision of this information "to facilitate a woman's autonomous decision-making by ensuring her fully informed consent").

193 See Lang, supra note 184, at 1371 (arguing that City of Akron v. Akron Ctr. for Reprod. Health, Inc., 462 U.S. 416, 444-45 (1983), stands for the proposition that "informed consent disclosures, at a minimum, cannot seek to manipulate or mislead a woman making her constitutionally-protected choice"); $c f$. Siegel, supra note 184, at 1752 ("Government may 'persuade' a woman to carry a pregnancy to term; it may not, however, manipulate, trick, or coerce her into continuing the pregnancy."). Siegel seems to be focusing on the effects prong, rather than the purpose prong, but the constraints that she observes should also limit the government's purpose for acting. Jeremy Blumenthal invokes the state's purpose when he suggests that the state may not provide false information or use language "so explicitly one-sided that the clear intent is for a woman to withhold her consent to an abortion, rather than even to pay lip service to the notion of encouraging a fully informed, reasoned, decision-making process." Blumenthal, supra note 192, at 12 (emphasis altered). On my reading, there is nothing inherently wrong with an intent to convince the woman to withhold consent. But the state may not act with the intent to trick her or mislead her into withholding consent. Thus, providing misleading or one-sided "information designed to bias a woman's decision" can violate the purpose prong. Id. at 32 .

$194 C f$. Brownstein, supra note 41, at 885 n.58 (explaining that the permissible purposes of protecting women's health and informing her free choice "are uniquely relevant to and consistent with the Court's understanding of the nature of the right to have an abortion itself").

195 Casey, 505 U.S. at 987 (Scalia, J., concurring in the judgment in part and dissenting in part) (internal quotation marks and brackets omitted).

196 Informed consent laws are motivated in part by concerns for women's health. Much of the information that they mandate concerns the alleged risk to the woman from abortion. See, e.g., Mailee R. Smith, Informed Consent Laws: Protecting a Woman's Right to Know, in DeFENDING LIFE 2010: Proven STRATEGIES FOR A PRO-LifE AMERICA, supra note 11, at 75, 75 ("Abortion clinics all too often fail to provide adequate and accurate information to women considering abortion. As a result, many women 
regulations, "the number of abortions decreases because women are informed, not because informed consent laws are burdensome."197

To these ends, Americans United for Life has drafted the "Women's Right to Know Act"-model legislation that insists that the "knowledgeable exercise of a woman's decision to have an abortion depends on the extent to which she receives sufficient information to make an informed choice."'198 The act therefore mandates that women seeking abortions be informed of many things, including the probable gestational age of the fetus, the "probable anatomical and physiological characteristics of the unborn child at ... the time the abortion is to be performed," the availability of child care support services and adoption services, the fact that the father is legally obligated to assist in the support of the child, and - when the abortion will take place after the twenty-week mark - the alleged fact that the fetus would likely feel pain during the abortion. ${ }^{199}$ The articulated primary "purpose[] of this Act" is to "[e]nsure that every woman considering an abortion receives complete information on abortion and its alternatives, and that every woman submitting to an abortion does so only after giving her voluntary and fullyinformed consent to the abortion procedure."200

Similarly, mandatory ultrasound requirements are enacted to

ensure an [sic] truly informed choice because they allow a woman to see her unborn child as he or she really is .... Medical evidence indicates that women feel bonded to their children after seeing them on the ultrasound screen. Once that bond is established, ... a woman no longer feels ambivalent toward her pregnancy and actually begins to feel invested in her unborn child. 201

Thus, she is discouraged from having an abortion. The state's ultimate interest in protecting fetal life is advanced by means chosen not to hinder the woman's decision, but rather to inform her decisionmaking and to discourage her from exercising in ignorance her right to choose.

are physically and psychologically harmed by the abortion process."); Paprocki, supra note 151, at 29 ("Abortion advocates work hard to bury the studies and stories that document abortion's negative health - and even deadly - consequences for women ...."). But, as noted above, pro-life advocates often view promoting women's health as a reason for choosing particular means of protecting fetal life. See also supra notes 147-51 and accompanying text. And, in any event, these laws are also clearly motivated in part by the purpose to "[p]rotect unborn children from a woman's uninformed decision to have an abortion." AMS. UNITED FOR LIFE, Women's Right to Know Act, in DEFENDING LiFE 2015: Celebrating Ten Years of DeFending Life, supra note 7, at 285, § 2(b)(2).

197 Smith, supra note 196, at 80.

198 Women's Right to Know Act, supra note 196, § 2(a)(2).

199 Id. $\S \S 4-5$, at $287-89$

200 Id. $\$ 2(\mathrm{~b})(1)$; see also Smith, supra note 196, at 79 ("Myth: Informed consent laws threaten a woman's right to choose. Fact: Informed consent laws do not prevent a woman from choosing abortion. Rather, such laws ensure a woman makes an informed choice. Those who claim to be 'pro-choice' should want to give women the objective information needed to make true choices."). 
If that is, in fact, what the state is seeking to do, then these laws do not violate the purpose prong. Such a purpose is surely paternalistic. ${ }^{202}$ But it is not an improper one under Casey.

The purpose prong is therefore neither nonexistent nor incoherent. Even though the state is allowed to pursue its interest in protecting fetal life, not every abortion restriction is enacted for a permissible purpose. And, on the flip side, even though the state is not allowed to act with the purpose to hinder a woman's choice, not every abortion restriction is enacted for an impermissible purpose, either. Regulations can seek to influence the choice without seeking to hinder it. The function of Casey's purpose prong, then, is to identify whether the state is pursuing its goal of protecting fetal life (or advancing some other valid interest) through means chosen for valid reasons, such as to facilitate or influence the woman's choice, or means chosen for invalid reasons, such as to undermine or deny the woman's choice. ${ }^{203}$

202 See Gonzales v. Carhart, 550 U.S. 124, 185-86 (2007) (Ginsburg, J., dissenting); Jeremy A. Blumenthal, Emotional Paternalism, 35 FLA. ST. U. L. REV. 1, 45-47 (2007).

203 In a recent article, Linda Greenhouse and Reva Siegel argue that "Casey's undue burden framework requires courts to differentiate the state's interests in protecting potential life and women's health," and that courts must ensure that a TRAP regulation ostensibly enacted for purposes of protecting women's health was not actually "a backdoor way of protecting potential life." Greenhouse \& Siegel, supra note 14, at 1432, 1472; see also id. at 1452-53 ("Acknowledging a fetal-protective justification for the laws - given the laws' role in forcing clinics to close - would plainly violate the constitutional limits Casey imposes on the means by which states can protect unborn life."). Their argument appears to be that the only permissible means of pursuing the interest in protecting fetal life are ones designed to influence the woman's choice through persuasion. See Linda Greenhouse \& Reva B. Siegel, The Difference a Whole Woman Makes: Protection for the Abortion Right after Whole Woman's Health, 126 YALE L.J. F. 149, 155 (2016) (arguing that "Casey imposed crucial restrictions on the means by which the government could protect fetal life: . . . states can protect potential life [only] by persuading a woman to carry a pregnancy to term"). If the state's true interest is in protecting women's health, then it is permitted to impose regulatory burdens (so long as they are not undue in effect). But if the state's true interest is in protecting fetal life, then any regulatory means that are not designed to persuade the woman to choose to carry her pregnancy to term are automatically invalid.

Twenty years ago, Robert Goldstein similarly argued that "the central premise of the undue burden test is that the state may further its interest in the fetus before viability only by assuring the woman's careful choice through structuring the decisionmaking process and by expressing ideas and communicating facts to educate and influence her." Robert D. Goldstein, Reading Casey: Structuring the Woman's Decisionmaking Process, 4 WM. \& MARY BILL RTS. J. 787, 803 (1996) (citing Planned Parenthood of Se. Pa. v. Casey, 505 U.S. 833, 877 (1992) (plurality opinion)); see also id. at 802 ("The undue burden test should not be seen as an invitation to adopt hostile legislation provided the legislature does not go 'too far' in the eyes of the Court. Rather, the joint opinion aims at an altogether different approach to abortion regulation: to authorize more leeway for the states to structure the woman's decisionmaking process, and to open up the expressive channels of speech to the pregnant woman while she is engaged in deliberation about her choice."). In Goldstein's view of the Casey plurality opinion, "the state can realize its interest in fetal life from the beginning of pregnancy only by informing the woman's choice, not by burdening it; because Casey preserves the woman's choice, educating her choice is the only means of protecting the fetus." Id. at 805 n.48. In other words, "the interest in the fetus justifies [government] speech, not regulation." Id. at 804 n.48. But see Gonzales, 550 U.S. at 157 ("The government may use its voice and its regulatory authority to show its profound respect for the life within the woman." (emphasis added)); id. at 158 (noting that "the State, from the 


\title{
IV. HOW PREVALENT MUST THE IMPERMISSIBLE PuRPose HaVE BEEN?
}

\author{
But what if the state simultaneously had both permissible and impermis- \\ sible reasons for choosing its means of regulation? \\ The activists and legislators responsible for restrictive abortion laws really \\ do seem to believe that abortion is harmful to women's physical and
}

inception of the pregnancy, maintains its own regulatory interest in protecting the life of the fetus").

While Goldstein was certainly on to something important, and rightly focused on the woman's free choice as the heart of the right, his argument was too narrow. In pursuing its interest in potential life, the state can do more than just "educate" the woman. It can affirmatively seek to discourage her. And it can do so with more than just speech. The state could, for instance, provide welfare services (designed to help women who are struggling financially to cover the costs of raising an infant) to pregnant woman who come to an abortion clinic, but then change their minds and carry their pregnancies to term.

Those means would respect the dignity and autonomy of women, which Greenhouse and Siegel correctly recognize as the heart of Casey. See Greenhouse \& Siegel, supra note 14, at 1437 ("C Casey] authorizes the government to protect potential life by means that recognize and preserve women's dignity ...."); id. at 1442 (arguing that "Casey's core values" indicate that "the government may persuade women to forego abortion and thus to protect potential life - but only if the government employs modes of persuasion that are, in the Court's view, consistent with the dignity of women"). But there are many means of pursuing the interest in potential life that are consistent with women's dignity and autonomy. It is a mistake, I believe, to assume that the state, in choosing a means of protecting potential life, may act only with the purpose of informing or facilitating the woman's choice. (Thus, we should not read too much into Casey's awkwardly phrased statement that "the means chosen by the State to further the interest in potential life must be calculated to inform the woman's free choice, not hinder it," especially given that this sentence was specifically discussing the "purpose ... of placing a substantial obstacle in the path of a woman seeking an abortion." Casey, 505 U.S. at 877 (plurality opinion).) In Gonzales, for instance, the Court held that the state may seek to pursue its interest in fetal life through means chosen for the purpose of expressing respect for the dignity of human life generally, or protecting the integrity of the medical profession. See supra notes $154-58$ and accompanying text. Those purposes are unrelated to women's dignity and autonomy, but because they do not undermine women's dignity and autonomy, they are permissible. In choosing among means, the state may act for any purpose at all, except those affirmatively prohibited by Casey and its progeny (those listed in supra Part III.B.2) or otherwise forbidden by law. See Brownstein, supra note 41, at 891 (noting that purpose prong can be satisfied by "a purpose that is neither presumptively valid nor conclusively impermissible," but rather is "merely legitimate"). The state might, for instance, choose particular means for reasons of cost, administrability, or convenience.

Thus, contra Greenhouse and Siegel, I believe that the same basic purpose analysis governs, regardless of what ultimate interest the state is purporting to advance. The fact that a regulation was allegedly intended to protect women's health, but was really intended to protect fetal life, is not necessarily dispositive of the purpose question. Regardless of whether the law was enacted to serve the interest in health or in potential life, its "role in forcing clinics to close" would likely establish a violation of the effects prong. Greenhouse \& Siegel, supra note 14, at 1452-53. As for the purpose prong, whether the state's ultimate purpose is life, health, or both, the operative question is why the state chose to advance that purpose (or those purposes) by these particular means. Unless the answer is to strike at the abortion right, to hinder the woman's choice, to make abortions more difficult to obtain, or some other purpose that undermines the dignity and autonomy of women (such as a desire to force women into archaic gender roles, see supra note 170), the law survives the purpose prong. 
psychological health. ${ }^{204}$ And they really do seem to believe that women would be less likely to choose abortions if they were fully informed of the health risks, the nature of the abortion procedure, the development of the fetus, and the services available to women who choose not to abort.205 Thus, they often really are acting in pursuit of interests that Casey treats as permissible.

But they frequently tie those goals up with impermissible ones. Consider this explanation from Americans United for Life for one of its primary legislative initiatives:

The Women's Protection Project is a targeted legal strategy aimed at exposing abortion's harm to women .... By fully educating both legislatures and the general public regarding the health risks to women, we will achieve three distinct things. First, we will educate influencers in state houses, courts, and the general public on the false notion that abortion is safer than childbirth, and that women rely on abortion to achieve societal equality, thereby undermining the current underpinnings of the Roe decision. Second, women will be better protected from the abusive Big Abortion industry. Third, babies will be saved from abortion, as abortion clinics often choose to close their doors rather than bring clinics in line with necessary health regulations. ${ }^{206}$

The professed purposes behind this legislative initiative are both permissible (protecting women's health; informing women's decisionmaking) and impermissible (undermining Roe v. Wade; making the exercise of the right so burdensome that it will force clinics to close).

What should a court do with such a law? For instance, in a recent district court case, the trial judge made findings of fact after a bench trial that "(A) A purpose of the bill is to improve the health and safety of women undergoing an abortion," and "(B) Another purpose of the bill is to make it more difficult for abortion providers to legally provide abortions and therefore restrict a woman's right to an abortion." 207 What then? How can we disentangle the permissible purposes from the impermissible ones? In other words, how prevalent must the impermissible purpose have been for the law to be unconstitutional?

"[H] uman beings are complex," Andrew Verstein has recently observed, "and our motivations are often mixed. Introspection reveals that we often act for several conscious motives, not to mention the unconscious impulses we do not ourselves notice."208 "The problem of multiple motivations arises [not only] when individual legislators act for permissible as well as impermissible reasons, [but] also when some legislators act for permissible reasons, but

See supra note 196.

See supra notes 196-97 and accompanying text.

AMs. UNITED FOR LIFE, ANNUAL REPORT 2013-14, at 13 (2013-2014).

June Med. Servs. LLG v. Kliebert, 250 F. Supp. 3d 27, 59 (M.D. La. 2017). The court never analyzed whether this state of affairs does or does not represent a violation of the purpose prong. 
others for impermissible."209 As Verstein puts it, the complications associated with mixed motives "grow geometrically when we seek the motives of an organization" such as a legislature. ${ }^{210}$

This mixed motive problem is pervasive in constitutional law (and in many other areas as well). There is, unfortunately, no consistent and uniform answer in the cases. ${ }^{211}$ In a recent article, Verstein provides a helpful taxonomy of doctrinal approaches to the issue. Verstein explains that there are really only four rules used by courts. In ascending order of stinginess (from the plaintiff's perspective), the impermissible motive must be either: (1) simply present, such that any credible indication of impermissible motive taints the law; (2) a but-for cause of the government's action, such that the plaintiff can prevail if the impermissible purpose actually affected the lawmaking; (3) the primary motive - predominating over any legitimate motives; or (4) the sole motive for the government's action, such that the presence of any credible permissible motive saves the law. ${ }^{212}$

Of the few courts to address the issue in the abortion context, some have been remarkably parsimonious - essentially applying the "sole motive" test. At least one court has held that the plaintiff must prove that "none of the individual legislators approving the [law's] passage ... was motivated by a [permissible] desire ...."213 To similar effect, other courts have held that "an abortion regulation satisfies the purpose prong unless the regulation serves 'no purpose other than to make abortions more difficult."'214

These standards are indefensibly draconian. They would, given the inevitable prevalence of mixed motives in this area, render the purpose prong impotent. There will always be some legislators who can honestly say that they were motivated, at least in part, by permissible purposes such as protecting women's health. ${ }^{215}$

209 Daniel O. Conkle, Religious Purpose, Inerrancy, and the Establishment Clause, 67 IND. L.J. 1, 3 (1991).

210 Verstein, supra note 208, at 3.

211 See id. at 4-6 (noting the "doctrinal parochialism" has caused the law to develop divergently in different areas - "just the natural fruit of common law rulemaking").

212 See id. at 28-36.

213 Armstrong v. Mazurek, 906 F. Supp. 561, 567 (D. Mont. 1995), vacated, 94 F.3d 566, 568 (9th Cir. 1996), rev'd, 520 U.S. 968,976 (1997).

214 June Med. Servs. LLC v. Kliebert, 158 F. Supp. 3d 473, 527 (M.D. La. 2016) (quoting Planned Parenthood of Se. Pa. v. Casey, 505 U.S. 833, 901 (1992)) (citing Whole Woman's Health v. Cole, 790 F.3d 563, 586 (5th Cir. 2015)) (declaring this to be "the Fifth Circuit standard"). The courts that apply this standard are quoting, and unfairly misapplying, Casey's poorly worded approval of abortion-related medical record keeping requirements: "[]t cannot be said that the requirements serve no purpose other than to make abortions more difficult." Casey, 505 U.S. at 901 . It is impossible to believe that the Casey Court intended this off-hand remark to articulate an insurmountable standard. See Spece, supra note 69, at 100 (arguing that that "cryptic statement should not be used to coax out a sole purpose requirement"). Rather, the Court likely meant only to suggest that there were valid reasons for the requirement, and there was no indication of a nefarious purpose.

215 By the same token, and for the same reason, the most stringent rule - pursuant to which the mere 
The handful of other courts to address the issue in the abortion context have been only slightly more lax, applying the "primary motive" test - which allows for the possibility of multiple purposes, but finds a violation only if the improper purpose "was the predominant factor motivating the legislature's decision." 216

Generally speaking, and with the exception of a couple of contexts to be discussed momentarily, this approach makes little sense. For one thing, the question that it asks is often impossible to answer. As Ely long ago observed, "only a hopelessly result-oriented judge would be able to assert that he knew which was 'the' motivation or the 'dominant' motivation underlying the statute." 217 Rather, multiple "expectations probably were intertwined in the minds of most legislators, and evidence of a sort available only to the Almighty would be needed to sort them out or to assign them relative weights." 218

What is more, even if we could answer the question, the answer should not matter in any event. As Paul Brest famously noted, "an illicit motive may have been 'subordinate' and yet have determined the outcome of the decision."219 It makes no sense to let the state get away with legislating for improper purposes simply because those purposes were intertwined with valid ones. 220

The "but-for" test makes much more sense in most areas of constitutional law. ${ }^{221}$ In the analogous equal protection context, for instance, the Supreme

presence of any wrongful purpose is enough to doom a law - also does not make sense in the abortion context. Since mixed motives tend to permeate this area, that test would have the effect of dooming virtually all abortion regulation. To be true to Casey, the purpose prong should not be impotent, but it should not be omnipotent either.

216 Jane L. v. Bangerter, 102 F.3d 1112, 1116 (10th Cir. 1996) (citation and internal quotation marks omitted).

217 Ely, supra note 44 , at 1214

$218 I d$.

219 Brest, supra note 51, at 119.

220 See M. David Lepofsky, The Canadian Fudicial Approach to Equality Rights: Freedom Ride or Roller Coaster?, 55 LAW \& CONTEMP. PROBS. 167, 189 (1992) ("These earlier cases did not involve a law with multiple purposes, only one of which is unconstitutional. They involved 'single purpose' laws, where the single purpose was unconstitutional. However, this distinction should make no difference lest a legislature be able to piggy-back legislative purposes to enable it to do that which the Constitution forbids."); cf. Turner Broad. Sys., Inc. v. FCC, 512 U.S. 622, 679 (1994) ("It may well be that Congress also had other, content-neutral, purposes in mind when enacting the statute. But we have never held that the presence of a permissible justification lessens the impropriety of relying in part on an impermissible justification. In fact, we have often struck down statutes as being impermissibly content based even though their primary purpose was indubitably content neutral."); Ely, supra note 44, at 1267 (arguing "that the question of 'dominance' is one there can be no reason to ask" because if the legislators "employed an unconstitutional criterion of selection in making the choice in issue[,]" the "fact that ... they also may have been influenced by [permissible considerations] should be deemed irrelevant to whether the choice should be reviewed [under heightened scrutiny]").

221 See generally Brest, supra note 51, at 119 n.123 ("It is entirely possible that [the decisionmaker] had both objectives in mind, but the rule should be invalidated if the illicit objective played any material role in the decision."); Louis S. Raveson, Unmasking the Motives of Government Decisionmakers: A Subpoena for Your Thoughts?, 63 N.C. L. REV. 879, 956 (1985) ("Most, if not all, motive theorists appear to agree that the crucial issue is whether impermissible motives affected the outcome of the 
Court, relying on Brest, has explained that " $[\mathrm{r}]$ arely can it be said that a legislature or administrative body ... made a decision motivated solely by a single concern, or even that a particular purpose was the 'dominant' or 'primary' one."222 "The search for legislative purpose is often elusive enough, without a requirement that primacy be ascertained. Legislation is frequently multipurposed: the removal of even a 'subordinate' purpose may shift altogether the consensus of legislative judgment supporting the statute.”223 Thus, an equal protection plaintiff need only show that an improper "purpose has been a motivating factor in the decision ....".224 Doing so then "shift $[\mathrm{s}]$ to the [government] the burden of establishing that the same decision would have resulted even had the impermissible purpose not been considered." 225 If the government can make that showing, then it is no longer fair to say that the law was enacted out of the improper purpose. ${ }^{226}$ But if the government cannot make that showing, then the law is unconstitutionally tainted by, and was actually the product of, an illicit legislative purpose.

This approach - generally far more sensible and sophisticated than the others - is the one that courts should apply in abortion cases. ${ }^{227}$ Remarkably, however, it does not appear that any court has ever done so. Rather, in applying the "primary motive" rule instead, the lower courts have reflexively followed cases in two other areas of constitutional law-legislative

decisionmaking process.").

222 Vill. of Arlington Heights v. Metro. Hous. Dev. Corp., 429 U.S. 252, 265 (1977).

223 Id. at $265 \mathrm{n} .11$ (citation omitted) (quoting McGinnis v. Royster, 410 U.S. 263, 276-77 (1973)).

224 Id. at $265-66$.

225 Id. at 270-71 n.21.

226 See id.; cf. Brest, supra note 51, at 117 ("If the decisionmaker gave weight to an illicit objective, the court should presume that his consideration of the objective determined the outcome of the decision and should invalidate the decision in the absence of clear proof to the contrary.").

227 Cf. Spece, supra note 69, at 98-100 (briefly referencing this test in the course of discussing the purpose prong). To anticipate one possible objection, in the equal protection context, a finding of illicit purpose does not automatically invalidate a law; it simply triggers strict scrutiny. The law will still stand if the state can adequately justify it. See supra note 79 and accompanying text. By contrast,

[T] he purpose prong within the undue burden test does not serve as the trigger of a standard of review in which the government might justify an improper purpose by, for example, showing a compelling or important government interest. Rather, the purpose prong is itself the standard of review, which flatly proscribes government actions that have an improper purpose.

Spece, supra note 69, at 101. Perhaps the fact that the state still has an opportunity to justify the law in the equal protection context, but not in the abortion context, could be thought of as a reason to demand a higher showing of purpose in abortion law. But that would just undercut Casey. That this framework will be harder on the government in abortion cases than in equal protection cases is a consequence of the fact that the Casey Court made a choice not to afford the state a chance to justify abortion regulations enacted for improper purposes. If the state cannot show that a law that was partially motivated by improper purposes would have been enacted even without those purposes, then, under Casey, that law should not stand, because Casey holds that an improper purpose automatically invalidates an abortion regulation. 
redistricting and establishment of religion - in which that test governs. ${ }^{228}$ It appears that the first courts to address the issue chose the primary motive rule unthinkingly, analogizing to those areas - rather than, say equal protection - without reflection or analysis.229 And then the few courts that have subsequently applied the purpose prong just followed suit. 230

But those are not analogous areas of law. Those areas are unique. There are good reasons why the Court has resorted to the use of the generally dubious primary motive rule, in lieu of the generally sensible but-for rule, in those circumstances - reasons that are not applicable in the abortion context.

In the case of redistricting, the but-for rule could not possibly be applied because, pursuant to the Voting Rights Act, legislatures must take race into consideration in their decisionmaking process. ${ }^{231}$ We cannot ask whether the legislature would have made the same decision even without consideration of race because we affirmatively require it to consider race. Thus, we have to ask instead whether the racial considerations predominated; only then, as a matter of substantive law, does the purpose to consider race rise to the level of a wrongful one.232

228 See McCreary Cty. v. ACLU, 545 U.S. 844, 863-64 (2005) (holding that the government must not act "with the predominant purpose of advancing religion"); Miller v. Johnson, 515 U.S. 900, 916 (1995) ("The plaintiff's burden is to show ... that race was the predominant factor motivating the legislature's decision to place a significant number of voters within or without a particular district.”).

229 See Armstrong v. Mazurek, 94 F.3d 566, 567 (9th Cir. 1996) ("While the Supreme Court has not elaborated on the means of determining legislative purpose under the Casey standard, it has done so in other contexts. Legislative purpose to accomplish a constitutionally forbidden result may be found when that purpose was 'the predominant factor motivating the legislature's decision." (quoting Miller, 515 U.S. at 916)); see also Okpalobi v. Foster, 190 F.3d 337, 354 (5th Cir. 1999) ("We are not without guidance, however, as abortion law is not the only realm of jurisprudence in which courts are required to question whether a measure has been adopted for an impermissible purpose. Such an inquiry is also mandated in both voting rights and Establishment Clause cases."). Although the Supreme Court summarily reversed the Ninth Circuit's decision in Mazurek, it did not weigh in on this issue. See Wharton et al., supra note 24, at 345 \& n.152.

230 See, e.g., Karlin v. Foust, 975 F. Supp. 1177, 1210 (W.D. Wis. 1997) (applying the predominant purpose standard without analyzing why that standard was appropriate), rev'd in part, 188 F.3d 446 (7th Cir. 1999).

231 See Shaw v. Reno, 509 U.S. 630, 680 (1993) (Souter,J., dissenting) ("Unlike other contexts in which we have addressed the State's conscious use of race, electoral districting calls for decisions that nearly always require some consideration of race for legitimate reasons .... [L] egislators will have to take race into account in order to avoid dilution of minority voting strength in the districting plans they adopt.") (citations omitted); Terry Ao Minnis, Asian Americans \& Redistricting: The Emerging Voice, 13 J. L. SOC'Y 23, 36 n.50 (2011) (noting "that race must be considered during the redistricting process to ensure that any map considered complies with the Voting Rights Act").

232 See Miller, 515 U.S. at 916 ("The plaintiff's burden is to show, either through circumstantial evidence of a district's shape and demographics or more direct evidence going to legislative purpose, that race was the predominant factor motivating the legislature's decision to place a significant number of voters within or without a particular district."). For another reason why the redistricting cases are inapposite, see Spece, supra note 69, at 100 (noting that the predominant purpose test is a deferential one, and arguing that "[d]eference is appropriate in the voting rights cases... because voting is inherently political and allocation of voting power implicates multiple conflicting important rights. There is no similar justification for deference in the present context." (footnote omitted)). 
The but-for test would also be unworkable in the Establishment Clause context. For many devout people, including many devout legislators, it is impossible to separate their religious motivations from their secular ones; everything they do, they do in substantial part for religious reasons. Every end that they seek, and every means that they choose to get there, is necessarily permeated with religious motivations. ${ }^{233}$ We cannot productively ask them whether they would have made the same choice without those motivations, because they cannot even imagine what it would mean to make any choice, or take any action, without those motivations.

There is nothing analogous about abortion. Abortion is much more similar to (non-redistricting) equal protection. Legislators need not, and constitutionally may not, act for certain purposes. We recognize that it is, unfortunately, inevitable that some of them will sometimes be motivated at least in part by those purposes. Given the passionate, fervent beliefs of many prolife legislators, it would be virtually impossible - or at least hopelessly naïeto expect them always to purge those constitutionally impermissible intentions entirely from their decisionmaking. But it is both possible and sensible to ask whether the legislature would have reached the same decision in the absence of those motivations. ${ }^{234}$ And if the state cannot show that it would have, then the law is unconstitutionally tainted.

233 See, e.g., Joshua Keating, Rubio Gets Religion in Iowa, Slate (Jan 28, 2016, 11:19 PM), http://www.slate.com/blogs/the_slatest/2016/01/28/seo_marco_rubio_talks_jesus_religion_at _fox_news_gop_debate.html (quoting Senator Marcu Rubio as saying at a presidential debate, "And when I'm president, I can tell you this, my faith will . . . influence the way I'll govern as president .... Because in the end, my goal is not simply to live on this Earth for 80 years but to live an eternity with my creator. I will always allow my faith to influence everything I do.”); Holly Meyer, Lawmaker Prayer Group Focuses on Religious Freedom, TENNESSEAN (Feb. 28, 2017, 12:58 PM), http://www.tennessean.com/story/news/religion/2017/02/28/lawmaker-prayer-group-focusesreligious-freedom/97305598/ (quoting Representative Mark Pody as saying, "There is no separation for me. Everything I do is going to be based on scripture. How I vote is going to be based on my biblical values as well as the Constitution, but I believe that my biblical values are the first things that I would turn to.").

234 It is true, of course, that the vast majority of pro-life sentiment is religious in nature (which is why it would be naive to expect all legislators to avoid entirely the taint of impermissible purposes.). But, unlike the Establishment Clause cases, Casey does not ask whether the legislature possessed an abstract intent to advance religion - an intent that cannot be disentangled from other motivations for many lawmakers. Casey asks about particular wrongful purposes - such as seeking to make it harder to obtain an abortion - that, while perhaps religiously motivated for many people, could be purged from the decisionmaking process by any conscientious legislator committed to following her oath of office. See Johnsen, supra note 10, at 1373-74 (describing the decision of a strongly pro-life legislator to oppose a proposed abortion restriction because, even though she personally would "like to see abortion clinics closed," she recognized that that was not a permissible motivation, and that the true "goal" of the bill was not to protect women's health, but rather "to shut down the clinics"). 


\section{How Does One Prove AN IMPERMissible PuRPose?}

The burden should therefore be on the plaintiff to show that an improper purpose was a motivating factor in the decision to enact the abortion regulation (thus shifting the burden back to the state to show that the law would have been enacted even in the absence of the improper purpose).

But how can a plaintiff go about making that showing? Casey does not say. ${ }^{235}$ The easiest cases, of course, are ones in which the legislature openly admits, in the text of the statute, that it was acting for one of the forbidden purposes. For instance, when the Utah legislature included within an abortion-restricting statute a provision creating an abortion litigation trust account to fund legal efforts to overturn Roe v. Wade, the Tenth Circuit had little problem finding a clear violation of the purpose prong. ${ }^{236}$ Those means were clearly chosen to strike at the abortion right.

But, obviously, those cases are extremely rare. Laws intended to restrict abortion rights do not typically begin, "In order to make it harder for women to obtain abortions, be it enacted ...." Legislators are generally wise enough to articulate only permissible purposes, such as protecting women's health.

Some courts have indicated that the inquiry should stop there. So long as the professed purposes in the statutory text do not "facially indicate" a wrongful intent, they say, the purpose prong is satisfied. ${ }^{237}$

But that cannot possibly be correct. For one thing, even when the statutory text is silent, the state could openly concede an improper purpose in litigation, such as happened in a case in which the state, in its appellate brief, "in essence concede[d] that the [challenged] section was intended to prevent the nontherapeutic abortion of nonviable fetuses after twenty weeks because in the State's view women who seek such abortions have waited too long." ${ }^{238}$

Conceding only that much, there are courts that have opined that those easy and unmistakable cases are the only cases in which a violation of the

235 See Metzger, supra note 96, at 2035 ("Casey provided no methodology for identifying a purpose to create an undue burden ...."); see also Okpalobi v. Foster, 190 F.3d 337, 354 (5th Cir. 1999) ("The Casey Court provided little, if any, instruction regarding the type of inquiry lower courts should undertake to determine whether a regulation has the 'purpose' of imposing an undue burden on a woman's right to seek an abortion.").

236 See Jane L. v. Bangerter, 102 F.3d 1112, 1116-17; see also Planned Parenthood of the Heartland v. Heineman, 724 F. Supp. 2d 1025, 1032 (D. Neb. 2010) (finding improper purpose where the "statute declares the Legislature's view that Roe v. Wade was a 'legislative intrusion of the United States Supreme Court' that 'removed the protection afforded the unborn' and that members of the Legislature 'expressly deplore the destruction of the unborn human lives which has and will occur in Nebraska as a consequence of [Roe]" (alteration in original) (citation omitted) (quoting NEB. REV. STAT. § 28-325(1-2) (2010))).

237 Planned Parenthood of Greater Tex. Surgical Health Servs. v. Abbott, 734 F.3d 406, 413 (5th Cir. 2013). 238 Bangerter, 102 F.3d at 1117. 
purpose prong can be found - that "the impermissible purpose prong of the undue burden test appears almost impossible to prove in the absence of a confession." "239 On this view, the proper "approach is very deferential, and a court's job is simply to determine whether any conceivable rationale exists." 240

But that too cannot be right. ${ }^{241}$ Courts defer to the legislature's articulated purpose, or to the existence of another conceivable valid purpose, only when they are employing rational basis review. ${ }^{242}$ That sort of deference is the very essence of rational basis review. ${ }^{243}$ But, as the Hellerstedt case just reminded us, it "is wrong to equate the judicial review applicable to the regulation of a constitutionally protected personal liberty [like abortion rights] with the less stringent review" demanded by the rational basis test. ${ }^{244}$ Rather, under Casey's heightened review, the "'purpose' inquiry is an assessment of the legislature's real purpose." 245

But how do we ascertain the real purpose? Courts and commentators have long acknowledged that "divining the real motives of lawmakers is a perilous enterprise and a notoriously tricky affair." 246 And yet, at the same time that it has insisted that courts must routinely undertake this inquiry in a wide range of contexts, ${ }^{247}$ the Supreme Court has never offered a comprehensive and sophisticated account of how to go about doing it. 248 legislative purpose is necessarily deferential and limited"); Okpalobi, 190 F.3d at 354 (arguing that courts "should typically afford a government's articulation of legislative purpose significant deference").

241 Cf. Weinberger v. Wiesenfeld, 420 U.S. 636, 648 (1975) ("But the mere recitation of a benign ... purpose is not an automatic shield which protects against any inquiry into the actual purposes underlying a statutory scheme.").

242 See, e.g., Farrell, supra note 44, at 27 ("In rational basis cases, courts ordinarily accord such statements the greatest deference.").

243 See Kitchen v. Herbert, 755 F.3d 1193, 1237 (10th Cir. 2014) (explaining that the essence of rational basis review lies in extreme deference and judicial restraint).

244 Whole Woman's Health v. Hellerstedt, 136 S. Ct. 2202, 2309 (2016).

245 Planned Parenthood of Greater Tex. Surgical Health Servs. v. Abbott, 951 F. Supp. 2d 891, 899 W.D. Tex. 2013) (emphasis added), rev'd in part, 748 F.3d 583 (5th Cir. 2014).

246 Jesse H. Choper, Religion and Race Under the Constitution: Similarities and Differences, 79 CORNELL L. REV. 491, 494 (1994) (citations and internal quotation marks omitted).

247 See supra note 104.

248 One commentator laments:

Over and over in its jurisprudence, the Court has acknowledged that legislative motivation is rarely clear or pure. Yet, it has failed, over time, to grapple in any realistic or disciplined way with the question of how invidious purpose can be identified and proven by plaintiffs, especially in those circumstances where "everybody knows" what the purpose of the law is but the legislative body has the good sense not to put the purpose of the law in the preamble.

Marie A. Failinger, Yick Wo at 125: Four Simple Lessons for the Contemporary Supreme Court, 17 MiCH.J. RACE \& L. 217, 256 (2012) (footnote omitted); see also Aziz Z. Huq, fudging Discriminatory Intent, 103 CORNELL L. REV. (forthcoming 2018) (manuscript at 6) (noting that "the cases are suggestive of uncertainty in regard to the evidentiary strategies that may be employed to surface relevant 
Still, even if the Court has not have given us a fully satisfying, detailed road map, it has surely provided us with a set of useful guideposts. The inquiry is, at present, more hodge-podge than systematic. "Determining whether invidious discriminatory purpose was a motivating factor demands," the Court tells us, "a sensitive inquiry into such circumstantial and direct evidence of intent as may be available." 249 Courts deciding cases in other areas of constitutional law have long recognized numerous sources of such evidence, and there is no reason not to conclude that "the established methods for assaying a legislature's purpose are valid in the abortion context" as well. ${ }^{250}$ What follows is a brief survey of the judicially recognized means of proving wrongful legislative purpose, and how they can be used in abortion cases.

\section{A. The Face of the Law}

Even where the law does not openly confess an impermissible purpose, courts can sometimes still discern evidence of one from a careful reading of the text. ${ }^{251}$ This can be true in the abortion context. ${ }^{252}$ For instance, in one case, a law ostensibly enacted to protect women's health gave abortion clinics only two weekend days to comply with its demanding terms - an impossibly short time period that betrayed a true intent to drive them out of business. ${ }^{253}$

\section{B. A Comparison with the Regulation of Similar Practices}

Courts often find wrongful legislative intent in circumstances in which similar practices - which raise the same concerns that the state claimed to be addressing - were not subjected to similar restrictions, either in the challenged statute or in any other. ${ }^{254}$ For instance, the Supreme Court once invalidated a requirement for a special use permit to build a group home for the mentally

motivation").

249 Vill. of Arlington Heights v. Metro. Hous. Dev. Corp., 429 U.S. 252, 266 (1977).

250 Okpalobi v. Foster, 190 F.3d 337, 356 (5th Cir. 1999).

251 See, e.g., Church of the Lukumi Babalu Aye, Inc. v. City of Hialeah, 508 U.S. 520, 534 (1993) ("First, though use of the words 'sacrifice' and 'ritual' does not compel a finding of improper targeting of the Santeria religion, the choice of these words is support for our conclusion.").

252 See, e.g., Okpalobi, 190 F.3d at 356 ("[T] he State contends that the purpose of Act 825 is to encourage a physician to inform a woman of all the risks associated with having an abortion. The Act's plain language refutes such a contention. Contrary to the State's assertions, the cause of action contained in Act 825 simply does not hinge on what or how much information a physician provides to a woman prior to performing an abortion.").

253 See Planned Parenthood of Wis., Inc. v. Van Hollen, 94 F. Supp. 3d 949, 995 (W.D. Wis. 2015), affd sub nom Planned Parenthood of Wis. v. Schimel, 806 F.3d 908, 911 (7th Cir. 2015).

254 See, e.g., Lukumi Babalu Aye, 508 U.S. at 535 ("It is a necessary conclusion that almost the only conduct subject to Ordinances $87-40,87-52$, and $87-71$ is the religious exercise of Santeria church members. The texts show that they were drafted in tandem to achieve this result."); id. at 536 ("Indeed, careful drafting ensured that, although Santeria sacrifice is prohibited, killings that are no more necessary or humane in almost all other circumstances are unpunished.”). 
disabled when no permit was required to build apartment houses, boarding houses, fraternities, dormitories, hospitals, nursing homes, or other similar buildings in the same location. ${ }^{255}$ The city claimed a number of permissible purposes for the requirement - such as the fact that the land in question was on a flood plain and the mentally disabled might have difficulty evacuating quickly, and the fact that a large group home would be out of character in a residential neighborhood full of single-family homes. ${ }^{256}$ But the Court noted that those same concerns were also raised by other permissible uses of the land that did not require a permit: Hospitals and nursing homes would also be difficult to evacuate in a flood, apartment buildings and dormitories would pose equal threats to the aesthetics of the neighborhood; et cetera. ${ }^{257}$ From this, the Court discerned that "requiring the permit in this case appears to us to rest on an irrational prejudice against the mentally retarded." 258

Similar dynamics are often at play with abortion regulations. ${ }^{259}$ For example, Judge Posner once based a finding of wrongful intent on a comparison of abortion regulations with the regulations governing other medical procedures:

Opponents of abortion reveal their true objectives when they procure legislation limited to a medical procedure - abortion - that rarely produces a medical emergency. A number of other medical procedures are far more dangerous to the patient than abortion, yet their providers are not required to obtain admitting privileges anywhere, let alone within 30 miles of where the procedure is performed. 260

There are a great many abortion regulations that are susceptible to this reasoning. ${ }^{261}$

255

257

258

259

260 (observing that "the legislation inexplicably singles out abortion procedures for special treatment when the evidence demonstrates that abortion is at least as safe as, and often much safer than, other outpatient procedures regularly performed in this State"), aff'd sub nom. Schimel, 806 F.3d 908; see also Greenville Women's Clinic v. Bryant, 222 F.3d 157, 198 (4th Cir. 2000) (Hamilton, J., dissenting) (finding wrongful purpose because the law was "riddled with unnecessary requirements . . . which depart from accepted medical practice"); Planned Parenthood of the Heartland v. Heineman, 724 F. Supp. 2d 1025, 1044 (D. Neb. 2010) ("No such legislative concern for the health of women, or of men, has given rise to any remotely similar informed-consent statutes applicable to other medical procedures, regardless of whether such procedures are elective or non-elective, and regardless of whether such procedures pose an equal or greater threat to the physical, mental, and emotional health of the patient."). 


\section{A Bad "Fit" Between Means and Ends}

As noted in Part II, courts should sometimes conduct a means/ends fit analysis under Casey's effects prong - as a way of ascertaining the true benefits of the law for purposes of balancing them against the burdens imposed by the law. But a fit analysis can also be useful, in some cases, under the purpose prong. In all areas of constitutional law, the fact that a law either does not actually serve the interest that the state has proffered to justify it, or serves that interest only minimally - while imposing massive and unnecessary collateral damage along the way - can be used as evidence that the law was in fact motivated by a different, illicit purpose. ${ }^{262}$ That is to say, a fit analysis can be used to "smoke out" impermissible legislative purposes. 263

This is true in the abortion context as well. ${ }^{264}$ There are many abortion regulations enacted in the name of women's health that do not, in fact, serve

262 See, e.g., Sorrell v. IMS Health Inc., 564 U.S. 552, 574-75 (2011) ("TThe challenged statute] does not advance the State's asserted interest in physician confidentiality. The limited range of available privacy options instead reflects the State's impermissible purpose to burden disfavored speech."); Romer v. Evans, 517 U.S. 620, 635 (1996) ("The breadth of the amendment is so far removed from these particular justifications that we find it impossible to credit them.").

263 See supra note 80 and accompanying text.

264 See, e.g., W. Ala. Women's Ctr. v. Miller, Civil Action No. 2:15cv497-MHT (WO), 2017 WL 4843230, at *8 n.9 (M.D. Ala. Oct. 26, 2017) (noting in dicta that "[] egislative purpose may be inferred from the extent to which the statute actually furthers, or fails to further, the purported state interests," and "the fact that the school-proximity law may do little or nothing for the stated purpose suggests that the law's actual purpose may have been to place a substantial obstacle in the path of a woman seeking an abortion, and that the law would therefore fail the undue-burden test independent of its effects" (citation and internal quotation marks omitted)); Brownstein, supra note 41, at 885-86 ("The mere recitation of a presumptively valid purpose should not be allowed to mask an impermissible state goal. Thus, a law requiring a woman considering an abortion to consult with everyone in her neighborhood before making that decision could not be successfully justified as serving the purpose of informing the woman's free choice. Such a law not only creates a substantial obstacle to exercising the right to have an abortion; its egregious impact significantly undermines the state's credibility as to the law's asserted purpose."). As explained in Parts II and III, the purpose prong does more than simply smoke out hidden, nefarious purposes. It categorically, substantively precludes the state from acting out of certain purposes, whether they are disguised or not, in choosing the means of proceeding. Still, a smoking out analysis can surely be performed under the purpose prong.

Priscilla Smith argues that "the purpose prong is serving two distinct functions": first, "as a proxy for a determination of whether legislation in fact serves ... the group of interests that the Supreme Court identified in Roe and Casey are valid reasons for the regulation of abortion"; and second, "to serve the 'smoking out' function ascribed by many scholars to any 'heightened' scrutiny analysis, which determines whether the legislation is serving a hidden illegitimate purpose." Smith, supra note 24, at 1137 (footnote omitted). Smith argues that courts are wrongfully conflating those two distinct functions, and she claims that Casey "requires courts to undertake a first function review of purpose" by conducting a fit analysis to determine whether the law really serves the state's claimed interest. Id. at 1137, 1139-40.

I do not share that conceptualization. The purpose prong is concerned with one thing only: identifying the actual purpose behind the law. A fit analysis can be a method of doing so, but it is not the only method, and it might not be useful in every case. In addition, when courts do perform 
that interest to any meaningful degree.265 That disconnect, especially when it should have been obvious to the legislators, suggests that the claimed interest in health was pretextual 266 - that the state was really seeking to protect fetal life, and that it was doing so by means chosen not to protect women's health, but rather to limit women's access to abortion. This was likely the case with the law struck down in Hellerstedt. Although the Supreme Court performed its fit analysis under the effects prong, ${ }^{267}$ and did not openly discuss legislative purpose, that same analysis could have been used to evince a violation of the purpose prong. ${ }^{268}$ Linda Greenhouse and Reva Siegel explain:

This evidence-based balancing of the law's benefits and burdens calls into question Texas' very purpose in enacting the state's health-justified restrictions on abortion. While the majority never explicitly states that Texas enacted the admitting privileges and surgical center requirements with a purpose to obstruct women's access to abortion, the Court's deep skepticism of the state's actual motivation shines through the opinion. The Court repeatedly observes that the restrictions served little or no health benefit, and takes account of many ways the law adversely affected women's access. . . Whole Woman's Health provides a textbook illustration of how a court can show unconstitutional purpose . . . .269

a fit analysis in the name of purpose, they are, in fact, seeking to "smoke out" a hidden, wrongful motivation. See Brief of Constitutional Law Scholars, Amici Curiae Supporting Petitioners at 20, Whole Woman's Health v. Cole, 790 F.3d 563 (5th Cir. 2015) (No. 15-274), 2016 WL 106616 (noting that, in many areas of constitutional law, courts conduct a means/ends "fit" analysis in order to smoke out illegitimate purposes). As I see them, Smith's two functions are actually one and the same.

265 See note 16 and accompanying text.

266 See Planned Parenthood of Wis., Inc. v. Van Hollen, 738 F.3d 786, 790 (7th Cir. 2013) (finding that "the lack of any demonstrable medical benefit for [the] requirement either presented to the Legislature or [to] this court" was "certainly evidence that Wisconsin Legislature's only purpose in its enactment was to restrict the availability of safe, legal abortion in this State" (alteration in original) (quoting Planned Parenthood of Wis., Inc. v. Van Hollen, No. 13-cv-465-wmc., 2013 WL 3989238, at *10 n.26 (W.D. Wis. Aug. 2, 2013)) (internal quotation marks omitted)); Greenhouse \& Siegel, supra note 14, at 1433 ("A weak factual basis for the health interest asserted may supply objective evidence of a purpose to impose a substantial obstacle to women seeking an abortion."). 267 See supra notes $96-97$ and accompanying text.

268 See Brief for Petitioner at 36-40, Whole Woman's Health v. Cole, 790 F.3d 563 (5th Cir. 2015) (No. 15-274), 2015 WL 9592289 (arguing that Texas' requirements for abortion facilities were "not reasonably designed to promote women's health").

269 Greenhouse \& Siegel, supra note 203, at 158 (footnotes omitted). As a practical matter, this method of proving wrongful purpose is probably of limited value in the abortion context, as it ends up being redundant. A showing that the law does not actually serve its proffered interests, or kills a spider with a sledge hammer, should generally be sufficient to establish an unconstitutionally undue burden under the effects prong, rendering a purpose analysis unnecessary (as in Hellerstedt). But one can imagine cases in which the regulation does not actually succeed in reducing access to abortion, and thus does not have the effect of imposing an undue burden, and yet the mere fact that it also does not serve its purported interest in women's health evinces an impermissible purpose. In addition, this method of proof is not always analytically distinct from the one that follows. There are many cases in which the court could conduct an analysis of the fit between the claimed purpose and the foreseeable (rather than actual) effects, and could infer a wrongful purpose from the fact that the legislature must have known that the law would not actually serve the proffered interest. 


\section{Foreseeable Effects}

The law has long recognized that courts can "sometimes infer an impermissible purpose from [a] statute's natural and reasonable effect." 270 This method of proof can be very helpful in the abortion context. ${ }^{271}$ Courts are reluctant to strike down a law pre-implementation under the effects prong. ${ }^{272}$ But the fact that it was foreseeable to the legislature that the law would likely impose a substantial obstacle in the path of women seeking to exercise their abortion rights can be powerful evidence supporting immediate invalidation of the law under the purpose prong. ${ }^{273}$ Foreseeability is especially potent evidence of wrongful intent when the plaintiff can show either (1) that the legislators were aware and seemingly impressed that similar laws had imposed substantial obstacles in other states, ${ }^{274}$ or (2) that the legislators must have known that the state could just as easily have achieved its ostensible goals through other means that would not be likely to impose the same burdens. ${ }^{275}$

270 Nelson, supra note 104, at 1791 (citation and internal quotation marks omitted); see, e.g., United States v. Windsor, 133 S. Ct. 2675, 2694 (2013) (explaining that a statute's "operation in practice confirms [its] purpose."); Church of the Lukumi Babalu Aye, Inc. v. City of Hialeah, 508 U.S. 520, 535 (1993) ("Apart from the text, the effect of a law in its real operation is strong evidence of its object.”); Theodore Eisenberg \& Sheri Lynn Johnson, The Effects of Intent: Do We Know How Legal Standards Work?, 76 CORNELL L. REV. 1151, 1179 (1991) (noting that this remains one of the principal sources of evidence of wrongful legislative intent in race discrimination cases); Reva B. Siegel, Foreword: Equality Divided, 127 HARV. L. REV. 1, 15 (2013) (noting that courts often found intent this way in desegregation cases).

271 The Supreme Court has noted that, in this context as in others, courts "do not assume unconstitutional legislative intent ... when statutes produce harmful results[.]” Mazurek v. Armstrong, 520 U.S. 968, 972 (1997) (emphasis added). But those results, especially when they were obviously foreseeable, can nonetheless help to establish improper intent. See Vill. of Arlington Heights v. Metro. Hous. Dev. Corp., 429 U.S. 252, 266 (1977) (noting that, although generally "impact alone is not determinative," the effects of the law nonetheless "may provide an important starting point" in demonstrating that an impermissible purpose was a motivating factor in the legislative action).

272 See supra Part I.

273 See Planned Parenthood of the Heartland v. Heineman, 724 F. Supp. 2d 1025, 1046 (D. Neb. 2010) ("At this preliminary stage, this Court finds that Plaintiffs are likely to succeed on the merits of their Due Process liberty-and-privacy-interest claim, because the purpose of the bill appears to be the preservation of unborn human life through the creation of substantial, likely insurmountable, obstacles in the path of women seeking abortions in Nebraska."); Nancy Northup, Sneaking Around the Constitution: Pretextual "Health" Laws and the Future of Roe v. Wade, 26 HeAlth Matrix 1, 9 (2016) ("It is an inference in the law that you can derive purpose from effect. If you are closing 80 percent of the clinics in the state, it is evidence that your purpose was to do just that when you enacted the law.").

274 See June Med. Servs. v. Kliebert, 250 F. Supp. 3d 27, 55-56 (M.D. La. 2017) (deriving a finding of wrongful purpose in part from the fact that the state legislature was informed during the drafting process that a similar law had had "tremendous success in closing abortion clinics and restricting abortion access in Texas" (internal quotations omitted)).

275 Cf. Fried, supra note 49, at 61; Raveson, supra note 221, at 965 (citing Penick v. Board of Educ., 429 F. Supp. 229, 240 (S.D. Ohio 1977), aff'd, 583 F.2d 787 (6th Cir. 1978), affd, 443 U.S. 449 (1979)) (noting that courts have found discriminatory intent in segregation cases based on "evidence that a school board continually adopted policies that increased segregation when other alternatives would have eliminated or lessened it"). 


\section{E. Legislative History and Statements of the Legislators and Others Involved in the Legislative Process}

The Supreme Court has long held that, in demonstrating unconstitutional legislative purpose, the "legislative or administrative history may be highly relevant, especially where there are contemporary statements by members of the decisionmaking body, minutes of its meetings, or reports." ${ }^{276}$ This evidentiary vein can be a gold mine in abortion cases.

Given the passions that this issue entails, it is not surprising that many legislators and other government officials cannot help but make statements during the legislative process - either on the legislative floor, or in public along the lines of: "The intent of the legislation is to cause fewer abortions. So if [a] clinic ... had to shut down, then I think it is a positive day for the unborn." 277 Or, the purpose of the law was to "try and end abortion." 278

Courts can and should rely on those sorts of statements in striking down laws under the purpose prong. ${ }^{279}$ Conversely, courts can also rely on silence in the legislative history: For instance, that fact that, although the law was

276 Vill. of Arlington Heights v. Metro. Hous. Dev. Corp., 429 U.S. 252, 268 (1977); see also Church of the Lukumi Babalu Aye, Inc. v. City of Hialeah, 508 U.S. 520, 541-42 (1993); Eisenberg \& Johnson, supra note 270, at 1187 (noting that legislators' statements are, empirically, among the most effective means of proving wrongful intent). In some instances, plaintiffs can even procure or compel discovery or testimony from legislators regarding their subjective purposes. See Arlington Heights, 429 U.S. at 268; Huq, supra note 248, at 45-46 (addressing criticisms of purpose analyses based on the statements of decisionmakers); Raveson, supra note 221, at 881.

277 MJ Lee, Bill Dooms only Miss. Abortion Clinic, POLITICO (Apr. 5, 2012, 1:39 PM), http://www.politico.com/story/2012/04/bill-dooms-only-miss-abortion-clinic-074871 (quoting the bill's author, state Representative Sam Mims).

278 Irin Carmon, Mississippi's Last Abortion Clinic Fights to Stay Open - and out of SCOTUS, MSNBC (Apr. 22, 2015, 6:53 PM), http://www.msnbc.com/msnbc/mississippis-last-abortion-clinic-fights-stayopen-and-out-scotus (quoting Mississippi Governor Phil Bryant). Governor Bryant added, regarding the last abortion clinic in the state, that his "goal, of course, is to shut it down." Associated Press, Legal Woes for Mississippi's Only Abortion Clinic, USA TODAY (Jan. 11, 2013, 10:58 PM), http://www.usatoday.com/story/news/nation/2013/01/11/abortion-mississippi-women-clinic/ 1828289/; see also Gonzales v. Carhart, 550 U.S. 124, 174-75 n.4 (2007) (Ginsburg, J., dissenting) (noting statements by Members of Congress that the intent of the law at issue was to nullify a Supreme Court decision protecting the right to a particular abortion procedure); Marc Santora, Mississippi Law Aimed at Abortion Clinic Is Blocked, N.Y. TIMES, July 2, 2012, at A9 (noting that Lt. Gov. Tate Reeves's website bragged that a new law "not only protects the health of the mother but should close the only abortion clinic in Mississippi"); supra note 23 and accompanying text (noting similar statements regarding the Texas law at issue in Hellerstedt).

279 See, e.g., Planned Parenthood of the Heartland v. Heineman, 724 F. Supp. 2d 1025, 1032, 1043-44 (D. Neb. 2010) (relying on statements by legislators expressing contempt for Roe v. Wade); Planned Parenthood of Greater Ohio v. Hodges, 188 F. Supp. 3d 684, 693 (S.D. Ohio 2016) (finding "no doubt that the Ohio Legislature enacted Section 3701.034 for the purpose of placing a substantial obstacle in the path of a woman seeking to obtain an abortion" based on "a statement on the floor of the Ohio Senate" by a state senator who declared that "[W]e have an obligation ... to say ... to Planned Parenthood, until you get out of the business of termination of pregnancy, the destruction of human life, we are not going to choose to fund you." (alterations in original) (internal quotation marks omitted)). 
purportedly enacted to protect women's health, "the legislative record [was] devoid of any medical rationale." 280

In addition, legislative history need not be limited to the statements of the legislators. It can also include "evidence of the data and arguments presented to the institution, whether by outsiders or members, during the informationgathering and deliberative processes that led to the action." 281

That evidence can also be particularly helpful in abortion cases. ${ }^{282}$ Recall that most of the abortion restricting legislation in this country draws heavily on the efforts of advocacy groups like Americans United for Life.283 The Supreme Court has held that "the fact that an anti-abortion group drafted the [challenged] law," on its own, "says nothing significant about the legislature's purpose in passing it."284 But, recall further that those groups have often admitted that their intent in drafting and promoting their model legislation is, in substantial part, to undermine (and ultimately destroy) abortion rights and to limit access to abortion services. ${ }^{285}$ That evidence should be highly relevant. 286

\section{F. The Historical Background and the Specific Sequence of Events Leading to Enactment}

Courts have held that "[t] he historical background of the decision" and "[t]he specific sequence of events leading up to the challenged decision also

280 Planned Parenthood of Wis., Inc. v. Van Hollen, 94 F. Supp. 3d 949, 995 (W.D. Wis. 2015).

281 Raveson, supra note 221, at 974 n.543 (citing Vill. of Arlington Heights v. Metro. Hous. Dev. Corp., 429 U.S. 252, 268 (1977)); see also Eisenberg \& Johnson, supra note 270, at 1179.

282 See, e.g., W. Ala. Women's Ctr. v. Miller, 217 F. Supp. 3d 1313, 1322 (M.D. Ala. 2016) ("The plaintiffs have submitted newspaper articles, to which the State has not objected, that report that Reverend James Henderson, a leader of anti-abortion protesters outside the Huntsville clinic, drafted the bill that ultimately became the school-proximity law, with the purpose of shutting down the Huntsville clinic.”), appeal dismissed as moot, W. Ala. Women's Ctr. v. Williamson, 874 F.3d 1306, 1322 (11th Cir. 2017); June Med. Servs. LLC v. Kliebert, 250 F. Supp. 3d 27, 58 (M.D. La. 2017) (noting that among "[t]he evidence introduced to show the purpose of [the] Act" were "press releases, public statement [s], emails, and similar evidence produced by public officials, lobbyists, advocacy groups and others involved or interested in the drafting and passage of [the law]"); Spece, supra note 69, at 99 (noting that courts often look to the "statements, strategies, or actions of those involved in lobbying for" the statute).

283 See supra notes 11-13 and accompanying text.

284 Mazurek v. Armstrong, 520 U.S. 968, 973 (1997).

285 See Ruth Marcus, "Partial Birth," Partial Truths, WASH. POST, June 4, 2003, at A27 ("With this bill ... we are beginning to dismantle, brick by brick, the deadly edifice created by Roe $v$. Wade." (quoting Ken Connor, President of the Family Research Council) (internal quotation marks omitted)); supra notes 8-18 and accompanying text.

286 See, e.g., Fune Med. Servs., 250 F. Supp. 2d at 55-56 (basing a finding of improper purpose in part on the fact that "the Vice President and Executive Counsel of the Bio Ethics Defense Fund, an antiabortion advocacy group [which coordinated with the legislature in drafting the statute], sent the draft's primary legislative sponsor . . . an email regarding a similar statute passed in Texas that had 'tremendous success in closing abortion clinics and restricting abortion access in Texas."'). 
may shed some light on the decisionmaker's purposes."287 These factors too can be employed in abortion cases, particularly if there is evidence that the challenged statute was part of an orchestrated campaign to intimidate or crush particular abortion providers. ${ }^{288}$

\section{G. Departures from Normal Lawmaking Procedures}

"Departures from the normal procedural sequence also might afford evidence that improper purposes are playing a role." 289 That might be the case with abortion laws, if, for instance, it could be shown that the legislature enacted a law that purports to protect women's health without making the effort to investigate the actual benefits of the law that the legislature would ordinarily undertake. ${ }^{290}$

\section{H. Piling On}

Courts have sometimes found that the existence of multiple laws, all targeting the same practice, can be evidence of a wrongful legislative purpose behind each of them.291 Where a state has enacted numerous laws that all burden the provision of abortion services, that fact, while certainly not dispositive, could fairly be said to contribute to a finding of improper purpose. 292

287 Vill. of Arlington Heights v. Metro. Hous. Dev. Corp., 429 U.S. 252, 267 (1977); see also Church of the Lukumi Babalu Aye, Inc. v. Gity of Hialeah, 508 U.S. 520, 540-41 (1993).

288 See Mazurek, 520 U.S. at 980 (Stevens, J., dissenting) ("When one looks at the totality of circumstances surrounding the legislation, there is evidence from which one could conclude that the legislature's predominant motive was to make abortions more difficult."); Armstrong v. Mazurek, 94 F.3d 566, 567 (9th Cir. 1996) ("Such a forbidden purpose may be gleaned ... from examination of the process that led to its enactment. ... A determination of purpose in the present case, then, may properly require an assessment of the totality of circumstances surrounding the enactment...." (citations omitted)), rev'd, 520 U.S. 968 (1997).

289 Arlington Heights, 429 U.S. at 267.

290 See Wharton et al., supra note 24, at 381 (noting a case in which "the district court found an improper purpose based upon the rushed legislative process that provided 'no meaningful inquiry' into appropriate regulations for an abortion clinic" (citing Greenville Women's Clinic v. Bryant, 66 F. Supp. 2d 691, 705-10 (D.S.C. 1999), rev'd, 222 F.3d 157 (4th Cir. 2000))).

291 See, e.g., United States v. Bd. of Sch. Comm'rs of the City of Indianapolis, 573 F.2d 400, 412 (7th Cir. 1978) ("Even if no individual act carries unmistakable signs of racial purpose, a clear pattern is sufficient to give rise to a permissible inference of segregative intent.").

292 See Okpalobi v. Foster, 190 F.3d 337, 354-55 (noting that, "in conducting its impermissible purposes inquiries, the [Supreme] Court has looked to various types of evidence, including . . . other legislation concerning the same subject matter as the challenged measure," and finding that that evidence is relevant under Casey); Spece, supra note 69, at 100 ("If other enactments and the social and historical context are to be considered when exploring purpose or intent, it would be absurd to ignore what might be an onslaught of concomitant provisions meant to trammel a right."). 


\section{Discriminatory Application}

Finally, courts have found that wrongful purpose can sometimes be inferred from the way in which a law is being enforced. Even if a law is drafted in neutral terms, if in its application it is burdening only certain communities, that fact might betray an underlying impermissible intent. 293

Thus, in the abortion context, if a law ostensibly requires a broad range of medical facilities to obtain certain permits, or to endure certain forms of costly review, but the state in practice subjects only abortion clinics to those requirements, that disparity could evince an intent to burden abortion rights. ${ }^{294}$

None of these types of evidence is necessary to invalidate a law under the purpose prong. And some would likely not be sufficient on their own to do so. The court's job is to consider all of the available evidence collectively to make a determination whether the law was motivated in part by impermissible concerns and, if so, whether the government has met its burden of proving that the law would have been enacted even in the absence of those improper motives.

\section{CONCLUSION}

Under Planned Parenthood v. Casey, the state is free to regulate abortion in order to protect fetal life. But, in choosing how to go about doing so, it is not permitted to act with the intention of undermining abortion rights, hindering women's choices, or limiting their access to abortion services. Because this fundamental constitutional limit has been maligned, ignored, and misunderstood, half of the abortion right has gone unprotected for far too long. It is time for the courts to get serious about enforcing it.

293 See, e.g., Yick Wo v. Hopkins, 118 U.S. 356, 373-74 (1886).

294 See Planned Parenthood of Greater Iowa, Inc. v. Atchison, 126 F.3d 1042, 1049 (8th Cir. 1997) ("The plaintiff introduced evidence of specific clinics across Iowa that were structured similarly to its proposed project and which were exempted from CON review. The plaintiff also introduced evidence of specific family planning clinics across Iowa which were structured similarly to its proposed project, and which provided essentially the same services, but not abortions, and which were exempted from CON review. Moreover, Department officials could not explain the Department's deviation from its past practice of exempting similar clinics which did not offer pregnancy termination services to including the plaintiff's clinic which would offer such services."). 